\title{
Immune response modifiers in the treatment of asthma: A PRACTALL document of the American Academy of Allergy, Asthma \& Immunology and the European Academy of Allergy and Clinical Immunology
}

\author{
Mark Ballow, MD, ${ }^{\text {a }}$ Cezmi A. Akdis, MD, ${ }^{\text {b }}$ Thomas B. Casale, MD, ${ }^{\text {c }}$ Andrew J. Wardlaw, MD, ${ }^{\text {d Sally E. Wenzel, MD, }}{ }^{\text {e }}$ \\ Zuhair Ballas, MD, ${ }^{\mathbf{f}}$ and Jan Lötvall, MD ${ }^{\mathbf{g}}$ Buffalo, NY, Davos, Switzerland, Omaha, Neb, Leicester, United Kingdom, Pittsburgh, Pa, \\ Iowa City, Iowa, and Gothenburg, Sweden
}

Key words: Immune response modifiers, monoclonal antibodies, asthma, allergic diseases

Advances in molecular biology and immunology have led to a whole new algorithm for the treatment of autoimmune and allergic disorders from the traditional pharmacologic approach of drug therapy. These new therapeutic approaches, termed biologic immune response modifiers (IRMs), include therapeutic antibodies, small-molecule initiators of the innate immune system, and other biologic agents that target effector molecules, specific cells or cell-surface determinants, and cytoplasmic factors among others. More than $30 \mathrm{mAbs}$ have been approved for various indications, especially for autoimmune disorders, organ transplantation, infectious diseases, and cancer. More than 250 antibodies are currently in clinical development.

The origins of these therapeutic antibodies date back to the early 1970s, with the use of antithymocyte globulin made in rabbits for the treatment of renal allograft rejection. Cesar Milstein, who had a longstanding interest in the mechanism of antibody diversity, together with Georges Kohler, fused myeloma cells with lymphocytes from animals immunized with a specific antigen to create hybridomas. These immortalized B cells, secreting a single type of specific antibody, led to the term monoclonal antibodies. In 1984, Neils Jerne, Cesar Milstein, and Georges Kohler shared the Noble Prize in medicine for the discovery of the principles of mAb production. ${ }^{1}$

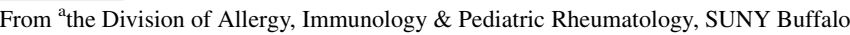
School of Medicine; ${ }^{b}$ the Swiss Institute of Allergy and Asthma Research (SIAF), University of Zurich; ${ }^{c}$ the Creighton University School of Medicine, Omaha; ${ }^{\mathrm{d}}$ the Institute for Lung Health, Department of Infection, Immunity, and Inflammation, Glenfield

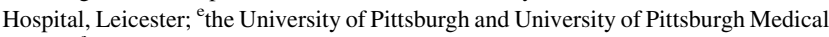
Center; ${ }^{\mathrm{f}}$ the Immunology Division, Iowa City VA Medical Center, and the Carver College of Medicine, University of Iowa, Iowa City; and ${ }^{\mathrm{g}}$ the Krefting Research Center, University of Gothenburg.

Disclosure of potential conflict of interest: M. Ballow receives research support from Grifols; serves on advisory boards for Baxter, CSL Behring, and Grifols; serves on data safety monitoring boards for Green Cross; and is a paid lecturer for Baxter and CSL Behring. C. A. Akdis receives research support from Novartis, PREDICTA: European Commission's Seventh Framework programme No. 260895, the Swiss National Science Foundation, MeDALL: European Commission's Seventh Framework Programme No. 261357, the Global Allergy and Asthma European Network, and the Christine Kühne Center for Allergy Research and Education; has provided legal consultation for Actellion, Aventis, Stallergenes, and Allergopharma; is President of the European Academy of Allergy and Clinical Immunology; is a fellow and research group member of the American Academy of Allergy, Asthma \& Immunology; is an ex-committee member of the Global Allergy and Asthma European Network; and is director of the Christine Kühne Center for Allergy Research and Education. T. B. Casale receives research support from MedImmune, Novartis, Stallergenes, Roche,
}

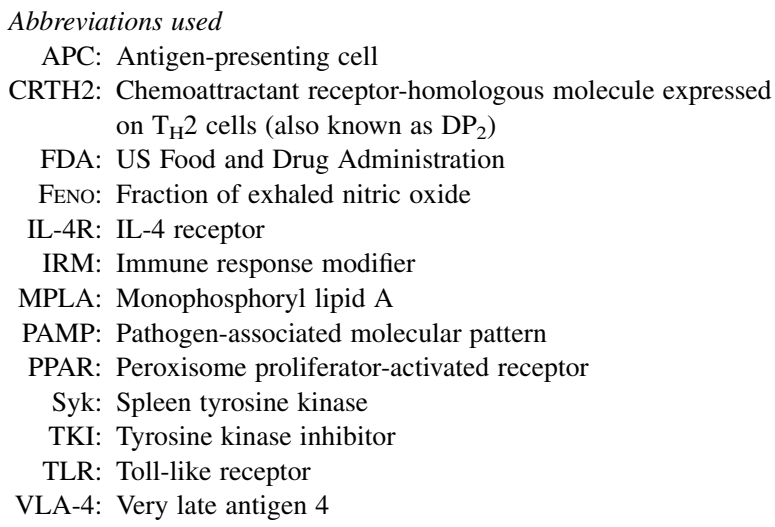

In 1986, OKT3 (muromonab), a CD3-specific murine mAb was the first US Food and Drug Administration (FDA)-approved mAb for the treatment of acute transplant rejection. The initial therapeutic mAbs were murine proteins. To make the antibodies less antigenic and thus less likely to elicit adverse reactions, chimeric mAbs were created by combining the murine antibody variable region that contains the antigen-binding region with the constant region of a human immunoglobulin molecule (Fig 1). Today, most

Genentech, Merck, and AstraZeneca; has consultant arrangements with Novartis, Merck, MedImmune, Stallergenes, and Genentech; and serves as Executive Vice President of the American Academy of Allergy, Asthma \& Immunology. A. J. Wardlaw has received grants from GlaxoSmithKline and Pfizer and has received fees for participating in a data monitoring board from Cephalon-TEVA. S. E. Wenzel receives research support from Amgen, GlaxoSmithKline, MedImmune, Sanofi Aventis, Array, and Genentech. Z. Ballas has received grant support from the Veterans Affairs Merit Review and the National Institutes of Health and has received royalties from UpToDate. J. Lötvall has received travel support from the European Academy of Allergy and Clinical Immunology; has consultant arrangements with GlaxoSmithKline, Novartis, AstraZeneca, and Merck; has received grant support from GlaxoSmithKline, Novartis, AstraZeneca, and Merck; is a paid lecturer for GlaxoSmithKline, Novartis, AstraZeneca, and Merck; has a patent on exosomes; and has received royalties from Wiley.

Received for publication April 5, 2012; accepted for publication April 9, 2012. Available online June 17, 2012

Corresponding author: Mark Ballow, MD, Division of Allergy, Immunology \& Pediatric Rheumatology, Women \& Children's Hospital of Buffalo, 239 Bryant St, Buffalo, NY 14222. E-mail: markbal.aird@gmail.com. $0091-6749 / \$ 36.00$

(C) 2012 American Academy of Allergy, Asthma \& Immunology doi:10.1016/j.jaci.2012.04.046 


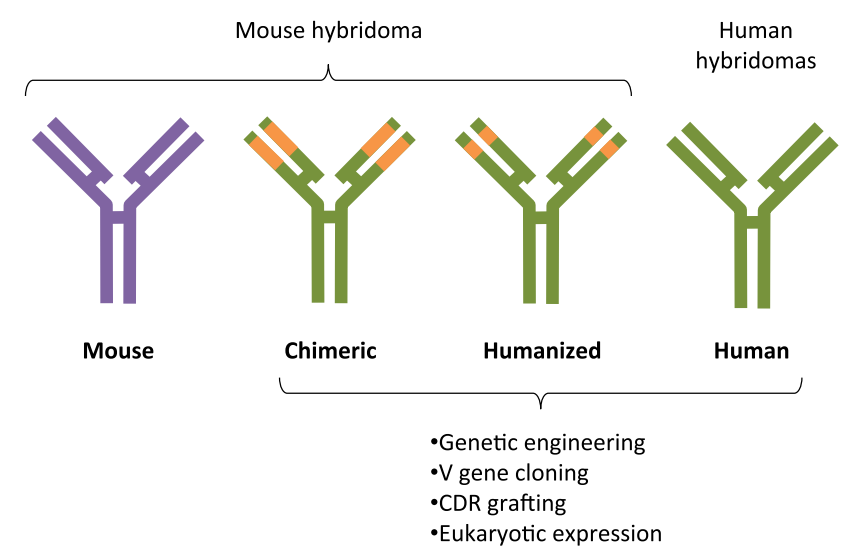

FIG 1. The transition of mAbs from all murine protein to chimeric and humanized mAbs in which part of the antigen-binding region is of the mouse (orange areas in the variable regions of the heavy and light chains) to a fully human mAb. $A D C C$, Antibody-dependent cell-mediated cytotoxicity. Reproduced with permission from Beck et al. ${ }^{128}$

therapeutic mAbs are either humanized, incorporating only the hypervariable region of the murine $\mathrm{mAb}$, or totally human mAbs made through genetic engineering. Table I shows the naming nomenclature for mAbs. A new nomenclature scheme by the United States Adopted Name Council supersedes previous schemes and adds naming protocols for posttranslational modifications. This new nomenclature scheme will not affect the names of previous mAbs. At the end of the article, we will discuss some of the newer innovative approaches and designs for therapeutic antibodies.

Because an extensive range of immunomodulators are being developed for asthma, it has been less obvious whether these are going to be effective in most or all patients with asthma or whether they will be therapeutic only in subgroups of asthmatic patients. Classically, asthma is defined as "a common chronic disorder of the airways that is complex and characterised by variable and recurring symptoms, airflow obstruction, bronchial hyperresponsiveness, and an underlying inflammation." However, the complexity of asthma is vast, with different patients having differences in natural history, severity, comorbidities, and response to different treatments. ${ }^{2}$ In fact, recent studies have proposed that patients with asthma express substantially different observable characteristics, such as phenotypes and endotypes of disease. Specifically, asthma phenotypes have been proposed to involve clinical characteristics, physiologic measures, inflammatory parameters, and laboratory data, as well as the response to different treatments. ${ }^{3,4}$ When the phenotypic characteristics of large cohorts of asthmatic patients are studied, diverse clusters of disease can be observed. ${ }^{5,6}$ Overall, these findings therefore argue that asthma is not a single disease but rather a syndrome of several subtypes with overall similar symptomatology among all patients with the diagnosis but with different fundamental mechanisms and pathobiological processes causing disease in different patients. Because the term phenotype does not incorporate mechanisms of the observed phenotypic characteristics, it was recently proposed that the term endotype should be used to define a distinct subtype of asthma with a distinct mechanism. ${ }^{7,8}$ Endotype is thus a different classification from phenotype and describes distinct disease entities with distinct immune and perhaps inflammatory pathophysiology. Thus the asthma syndrome is comprised of several endotypes, with most being mechanistically poorly understood. However, when medicines are developed to target very specific disease processes, as is the case with most novel immunomodulating therapies, it is likely that each medication will function only in specific asthma endotypes. As such treatments are developed, it is therefore crucial that patients with very distinct phenotypic characteristics, which are likely to encompass distinct asthma endotypes, are studied. Because IRMs are being developed for the treatment of asthma, linking the target molecule, cell, or both of each treatment to the asthma endotype is important for deciding the inclusion criteria in clinical studies and decisions for specific treatment selections.

In this report we will review the potential IRMs that target the immune and inflammatory pathways in asthmatic patients and discuss IRMs that might be potentially of interest in certain asthma endotypes. We will start our discussion with the most successful of the IRMs in asthmatic patients that target the $\operatorname{IgE}$ molecule. In addition, we will discuss other IRMs that target other components of the allergic pathway, such as cytokines, cellsurface receptors, and signaling molecules.

Our working definitions of an IRM is any substance or molecule that binds to or interferes with the binding to a receptor or a ligand on or in cells that are integral to a specific immune pathway, resulting in deletion, amplification, diminution, or functional shift of such cells.

\section{IRMs THAT NEUTRALIZE EFFECTOR MOLECULES}

Omalizumab (Xolair; Genentech, South San Francisco, Calif) is a $95 \%$ humanized $\mathrm{mAb}$ that forms soluble immune complexes with free $\operatorname{IgE}$ at the same site, which normally binds the highaffinity IgE receptor FceRI, thus preventing cross-linking of FceRI and subsequent basophil and mast cell activation. Omalizumab can reduce serum free IgE levels by $99 \%$ within 2 hours of administration and can reduce nasal allergen challenge responses within 2 weeks of therapy initiation. ${ }^{9}$ Omalizumab also decreases the expression of FceRI on basophils, dendritic cells, and monocytes within 7 days. ${ }^{9,10}$ In asthmatic patients omalizumab reduced serum, tissue, and sputum eosinophilia and numbers of cells positive for FceRI. After 16 weeks of treatment, omalizumab was shown to decrease B-cell numbers and $\mathrm{CD}^{+}, \mathrm{CD}^{+}$, and $\mathrm{CD}^{+}$cell numbers in lung tissue. ${ }^{11}$

In patients receiving inhaled corticosteroids alone or in combination with other agents, the addition of omalizumab has been shown to reduce the number of exacerbations (by about 50\%) and improve symptom scores, the need for inhaled corticosteroids, the use of rescue medication, asthma-related quality of life, and pulmonary functions (modestly). These effects appear independent of duration of treatment, age of the patient, and severity of asthma. ${ }^{12}$ The reasons for omalizumab being ineffective for some (approximately 40\%) patients are unknown. Improvements correlate with $\mathrm{IgE}$ level reductions, but free $\mathrm{IgE}$ levels in nonresponders are similar to those found in responders. ${ }^{13}$ Possible reasons include (1) the relationship between free IgE levels and FceRI expression, (2) the ratio of specific $\operatorname{IgE}$ to total $\operatorname{IgE}$, and (3) intrinsic cellular sensitivity. ${ }^{14}$ In a study by Bousquet et al, ${ }^{15}$ the global evaluation of the treatment effectiveness score was used to assess the response to omalizumab at 16 weeks of treatment. An excellent or good global evaluation of treatment effectiveness score was an effective predictor $(83 \%)$ of continued persistent response to omalizumab at week 32 of the study. Whether omalizumab can be stopped with sustained clinical efficacy is unclear and might depend on the duration of treatment. ${ }^{13,16}$ Omalizumab has a 
TABLE I. Monoclonal antibody nomenclature

\begin{tabular}{|c|c|c|c|c|c|}
\hline \multirow{2}{*}{$\begin{array}{l}\text { Prefix } \\
\begin{array}{l}\text { Varies, should be } \\
\text { euphonious }\end{array}\end{array}$} & \multicolumn{2}{|c|}{ Target inflix } & \multicolumn{2}{|c|}{ Source inflix } & \multirow{2}{*}{$\frac{\text { Suffix }}{-m a b}$} \\
\hline & -vir(r) -/-v- & Viral & $-0-$ & Mouse & \\
\hline & -ba(c)-/-b- & Bacterial & $-a-$ & Rat & - pab \\
\hline & $-\operatorname{le}(s)-$ & Infectious lesions & -e- & Hamster & \\
\hline & $-\operatorname{ci}(\mathrm{r})-/-\mathrm{c}-$ & Cardiovascular & $-\mathrm{i}-$ & Primate & \\
\hline & -ki-/-k- & Interleukin as target & $-x i-$ & Chimeric & \\
\hline & $-\mathrm{tu}(\mathrm{m})-/-\mathrm{t}-$ & Tumor & $-\mathrm{zu}-$ & Humanized & \\
\hline & $-\operatorname{li}(\mathrm{m})-/-1-$ & Immune & $-\mathrm{u}-$ & Human & \\
\hline & -ne-/-n- & Nervous system & -axo- & Rat/murine hybrid & \\
\hline & $-\operatorname{tox}(a)-$ & Toxin as target & & & \\
\hline & -fu(ng)-/-f- & Fungal & & & \\
\hline
\end{tabular}

If the antibody is conjugated to a product, such as a radiolabel or toxin (-tox-), this conjugate is identified by using a separate second word or chemical designation.

Examples: Adalimumab: Ada + lim (immune) $+\mathrm{u}$ (human) + mab (mAb) - mab to TNF- $\alpha$; Efalizumab: Efa $+\mathrm{Li}(\mathrm{m})(\mathrm{immune})+\mathrm{zu}($ humanized $)+\mathrm{mab}-\mathrm{mAb}$ to CD11a Adapted from the United States Adopted Names Council (USANC) at USAN@ ama-assn.org. The USANC is trisponsored by the American Medical Association, the United States Pharmacopeia Convention, and the American Pharmacists Association. In addition, the FDA cooperates with and is represented on the USANC. The USANC aims for global standardization and unification of drug nomenclature and related rules to ensure that drug information is communicated accurately and unambiguously. The USANC works closely with the International Nonproprietary Name Program of the World Health Organization and various national nomenclature groups.

$-m a b$, Monoclonal antibody; - $p a b$, polyclonal mixture of recombinant mAbs.

relatively good safety profile, but concerns have been raised about cancer, cardiovascular events, and anaphylaxis, which occurs in about $0.1 \%$ to $0.2 \%$ of patients. ${ }^{17,18}$

Pretreatment of patients with asthma and rhinitis with omalizumab has been shown to add efficacy and safety to allergenspecific immunotherapy and allowed more patients to reach the maintenance dose. However, it unknown how long you need to treat with both and whether you can stop the omalizumab after reaching maintenance immunotherapy. ${ }^{19,20}$

Omalizumab is also being investigated in patients with eosinophilic esophagitis, allergic bronchopulmonary aspergillosis, hyper-IgE syndrome, idiopathic anaphylaxis, food allergy, and chronic urticaria. ${ }^{21,22}$

\section{IRMs THAT AFFECT THE $\mathbf{T}_{\mathrm{H}} \mathbf{2}$ PATHWAY}

The $\mathrm{T}_{\mathrm{H}} 2$ pathway was first described in mice and human subjects well over 20 years ago. Not long after, speculation arose that the $\mathrm{T}_{\mathrm{H}} 2$ pathway was important in asthmatic patients based on murine studies that suggested that IL-13, in particular, was a critical molecule in the development of allergic inflammation and bronchial hyperresponsiveness. However, despite this initial enthusiasm, studies of molecules that modulated this $\mathrm{T}_{\mathrm{H}} 2$ pathway in human subjects were limited and slow to evolve. In fact, results of early studies with both a soluble IL-4 receptor (IL-4R) and an $\mathrm{mAb}$ to IL-5 were negative, further dampening enthusiasm. In recent years, the concept of asthma phenotyping, or ideally endotyping, has re-energized the approach to modulating the $\mathrm{T}_{\mathrm{H}} 2$ process. Approximately $50 \%$ of patients with mild untreated asthma have an airway $\mathrm{T}_{\mathrm{H}} 2$ signature. ${ }^{23}$ Thus focusing $\mathrm{T}_{\mathrm{H}} 2$ modulating therapies on this subgroup would seem important.

\section{INTERRUPTION OF THE IL-4, IL-13, AND IL-4R $\alpha$ PATHWAYS}

The first approach was to block the effects of IL-4 with a soluble IL-4R. A small 25-subject study used a corticosteroid withdrawal design in patients with mild-to-moderate asthma. ${ }^{24}$ A single nebulized dose of placebo was compared with 2 doses of soluble IL-4R over a 2 -week period after the discontinuation of inhaled corticosteroids. The highest dose was effective in limiting the decrease in lung function while preventing loss of symptom control or exacerbations. The level of exhaled nitric oxide also decreased with the highest dose, but no effect was seen on systemic markers of inflammation. A larger study of 62 subjects showed some effect at the highest dose $(3.0 \mathrm{mg})$, but the clinical changes were small. ${ }^{25}$ In addition, anti-IL-4 mAb had no significant effects on asthma parameters, suggesting that therapies aimed at IL-4 alone might not be sufficient to invoke positive therapeutic effects.

Although the early anti-IL-4 approaches only targeted IL-4, murine studies suggested that IL-13 would be a more important target for allergic inflammation. Thus pitrakinra, a recombinant IL-4 molecule mutated at 2 critical amino acid sites (arginine to aspartic acid at 121 and tyrosine to aspartic acid at 124), was developed. Pitrakinra bound competitively but nonfunctionally to cell membrane IL-4R $\alpha$, the signaling component of the heterodimeric receptor complex for both IL-4 and IL-13, therefore acting as an antagonist of these 2 cytokines. Initial studies were done with a subcutaneous injection of drug, which, likely because of the short half-life of the drug, were not very efficacious. However, a second study delivered the mutant IL-4/pitrakinra (or placebo) through the nebulized route to 32 patients with mild allergy for 4 weeks before comparing the posttreatment response to inhaled allergen challenge with the baseline response. ${ }^{26}$ Pitrakinra produced a modest and marginally significant decrease in the immediate response and an approximately $50 \%$ decrease in the late asthmatic response compared with baseline $(P<.0001)$, whereas placebo had no effect on either response. Similar to the earlier study of nebulized IL-4R, fraction of exhaled nitric oxide (FENO) values were again significantly decreased before allergen challenge compared with those after placebo, whereas there was a trend toward reduction in FENO values after challenge. In an 8 -week study, pitrakinra was studied in more than 500 patients with moderate-to-severe asthma receiving combination therapy. ${ }^{27}$ For the first 4 weeks, the combination therapy was held constant. Beginning at the fifth week, the long-acting $\beta$-agonist was first tapered and then followed by sequential halving of the inhaled corticosteroid dose, each at 2 -week intervals. The primary end point was time to the first exacerbation. Although there was no treatment effect in the overall 
population, in a prespecified subgroup analysis of subjects with more than 350 eosinophils $/ \mathrm{mm}$ in the peripheral blood, there was a significant reduction in time to first exacerbation, as well as the severity of the exacerbation, with the greatest effect seen with the highest dose. In addition to time to first exacerbation, symptom scores did not worsen in the pitrakinra-treated groups, with the greatest efficacy seen at the highest dose.

In a 12-week, phase 2, randomized, placebo-controlled study of a humanized $\mathrm{mAb}$ to IL-4R $\alpha$ (AMG 317), which prevents binding of IL-4 and IL-13 to their common receptor component, patients received weekly subcutaneous injections of placebo or varying doses $(75-300 \mathrm{mg})$ in patients with moderately symptomatic asthma. ${ }^{27}$ Despite promising efficacy in allergen challenge models, this particular humanized mAb to IL-4R $\alpha$ did not improve its 2 primary outcomes: the Asthma Control Questionnaire score and $\mathrm{FEV}_{1}$. Of note, despite the lack of efficacy, serum IgE levels were decreased by approximately $50 \%$ with the high dose. In an attempt to determine whether a subgroup might respond better to AMG 317, the subgroup with the worst Asthma Control Questionnaire score appeared to have a modest response to the highest dose of the drug. Despite this small signal, this particular antibody is not being taken forward in the treatment of asthma.

Using allergen challenge to investigate 2 neutralizing mAbs against IL-13 (which recognized different epitopes), Gauvreau et $\mathrm{al}^{28}$ saw a significant inhibition of both the early- and late-phase response with one but not the other. No effect on sputum eosinophil numbers or airway hyperresponsiveness was observed. In a recent study of an mAb directed against IL-13 (lebrikizumab), Corren et $\mathrm{al}^{29}$ reported a modest improvement of $5.5 \%$ in predicted prebronchodilator $\mathrm{FEV}_{1}$ (the primary outcome measure) in patients with moderate-to-severe asthma, including those taking long-acting $\beta$-agonists. ${ }^{29}$ Dividing the subjects into those with blood eosinophils, IgE, or both did not improve the identification of responders. However, when serum periostin levels was used to divide the population, those in the upper 50th percentile had an $8.2 \%$ improvement in $\mathrm{FEV}_{1}$ compared with the lowperiostin group, who had no improvement in predicted $F_{E V}$. Periostin had previously been identified as a molecule highly expressed by epithelial cells (and likely other cells) in response to IL-13 and therefore was suggested to be a serum $\mathrm{T}_{\mathrm{H}} 2$ biomarker. $^{23}$ Interestingly, FENO values were similarly predictive of response, and in fact, levels decreased with anti-IL-13 therapy. There was no effect on symptoms, but there was a $60 \%$ reduction in exacerbations in a $\mathrm{T}_{\mathrm{H}}$ 2-high group defined according to total IgE levels and peripheral blood eosinophil numbers. Thus a patient with an asthma endotype with increased serum periostin levels appears to be a good candidate for anti-IL-13 therapy.

\section{ANTI-IL-5}

The close association between eosinophils and asthma has been appreciated for many decades. ${ }^{30}$ In the 1980 s, a series of studies used bronchoscopy to demonstrate that eosinophilic airway inflammation was a feature of even mild asthma, and this was one of the justifications for the widespread introduction of inhaled steroids for patients with all severities of asthma. ${ }^{31}$ The idea that eosinophils were one of the major effector cells in asthmatic patients was underpinned by the paradigm that asthma was driven by $\mathrm{T}_{\mathrm{H}} 2$ mediated inflammation because there is a close relationship between $\mathrm{T}_{\mathrm{H}}$ 2-derived cytokines and eosinophil recruitment and function. However, the importance of eosinophils in asthmatic patients was called into question by early studies of 2 antibodies that neutralized IL-5, an obligate growth factor for eosinophil expansion. Leckie et al, ${ }^{32}$ in an allergen challenge study, found that the GlaxoSmithKline (Research Triangle Park, NC) antibody mepolizumab was very effective at reducing sputum and blood eosinophil numbers but had no effect on prechallenge airway hyperresponsiveness or the reduction in $\mathrm{FEV}_{1}$ during the early and late response. A subsequent clinical trial of mepolizumab in 362 patients with moderate asthma found no effect on standard asthma outcomes, including lung function, symptoms, and $\beta_{2}$-agonist use. There was a trend toward a reduction in exacerbations, but the study was underpowered to investigate this outcome. ${ }^{33}$

Kips et $\mathrm{al}^{34}$ undertook a small study to determine the safety of another anti-IL-5 antibody (SCH55700, reslizumab) developed by Schering-Plough (Deerfield, Ill) in patients with severe asthma. They found a modest improvement in $\mathrm{FEV}_{1}$ but no effect on other clinical parameters. There were 2 important caveats to these clinical studies. First, they did not target patients with eosinophilic disease. This is important because, as pointed out above, not all patients with asthma have evidence of excess eosinophils. ${ }^{35,36}$ Second, Flood-Page et $\mathrm{al}^{37}$ demonstrated in a study of patients with mild asthma (in which they also found no effect on standard asthma outcomes or airway hyperresponsiveness) that although mepolizumab caused a marked reduction in blood and sputum eosinophil numbers, it only reduced tissue eosinophil numbers by approximately $50 \%$. Even this might be an overestimate because some eosinophils in bronchial biopsy specimens would be within the blood vessels.

However, the most important weakness of all the studies discussed above was that they might have targeted the wrong outcome measure. There is actually very limited evidence that eosinophils are important in driving variable airflow obstruction, the classical physiologic measure that defines asthma. ${ }^{38}$ Because airway hyperresponsiveness, day-to-day symptoms, and bronchodilator use are closely linked to this physiologic abnormality, it means that studies that use these measurements as outcome measures of antieosinophil treatment will not be successful in showing any benefit. Asthma, particularly in its more severe forms, consists of 5 pathophysiologic abnormalities, which, although interrelated, are relatively distinct: airway hyperresponsiveness, bronchitis (eosinophilic or neutropenic airway inflammation), cough reflex hypersensitivity, lung damage as reflected in bronchiectasis and irreversible airflow obstruction, and extrapulmonary factors. ${ }^{39}$ Eosinophils are most closely linked to severe exacerbations. 40

Two recent, small, single-center studies have addressed the deficiencies identified above by investigating mepolizumab in patients with eosinophilic asthma by using severe exacerbations as the primary outcome. Nair et $\mathrm{al}^{41}$ investigated 18 patients with highly eosinophilic, oral corticosteroid-dependent asthma by using a steroid-reduction design and found a marked difference in the rate of exacerbations and the ability to reduce the dose of oral steroids between the active and placebo groups. As pointed out by Wenzel in a commentary on the article, ${ }^{42}$ the patients in this study represented a relatively small subgroup of patients with asthma-like airway disease, perhaps more akin to patients with hypereosinophilic disease, in whom mepolizumab had been shown to be beneficial, ${ }^{43}$ who might not necessarily have airway hyperresponsiveness or variable airflow obstruction. The extent to which this study can be generalized to the wider asthmatic population can be questioned. 
In contrast, the study by Haldar et $\mathrm{al}^{44}$ recruited 61 subjects with eosinophilic asthma from a difficult asthma clinic population in which at least $25 \%$ of the patients attending the clinic would meet the recruitment criteria of a history of severe exacerbations and a sputum eosinophilia of greater than 3\% despite high dose inhaled corticosteroids. They found a significant reduction of approximately $40 \%$ in the number of severe exacerbations over the 12-month course of the study. As in previous studies, there was a marked, although not complete, reduction in sputum eosinophil but not tissue eosinophil numbers. The greater the reduction in sputum eosinophil numbers, the lower the number of exacerbations. Strikingly, there was no difference between the active and placebo groups in the standard asthma markers of $\mathrm{FEV}_{1}$, airway hyperresponsiveness, day-to-day symptoms, or $\beta_{2}$-agonist use, although there was an overall improvement in quality of life, thus emphasizing the distinction between the pathophysiologic pathways that lead to variable airflow obstruction (presumably secondary to smooth muscle dysfunction) and those related to eosinophilic inflammation. Interestingly, there was an improvement in the computed tomographic scan appearances, suggesting an effect on airway remodeling. This effect was also suggested by a reduction in basement membrane thickening in the active group shown by Flood-Page et $\mathrm{al}^{45}$ in their studies with mepolizumab.

These studies have encouraged GlaxoSmithKline to undertake a multicenter study of mepolizumab in patients with eosinophilic asthma. In addition, Cephalon (Frazer, Pa) have obtained the rights to SCH55700 (as reslizumab) and are embarking on a program of studies investigating the antibody in eosinophilic asthma by using severe exacerbation as one of the outcome measures. They have already reported a 3-month study in patients with moderate eosinophilic asthma, which again demonstrated about a $50 \%$ reduction in exacerbations and, interestingly, a modest improvement in $\mathrm{FEV}_{1} \cdot{ }^{46}$ Lastly, MedImmune (Gaithersburg, Md) are taking forward an mAb (MEDI-563) that binds to the IL-5 receptor, preventing IL-5 binding and also inducing eosinophil cell death. ${ }^{47}$ This is particularly exciting because it offers a better chance of reducing tissue eosinophil numbers.

There is therefore increasing evidence that antieosinophil strategies will at least play an important role in preventing severe exacerbation of asthma in which the asthma endotype includes an important role for eosinophils. Current evidence suggests that these treatments are safe and well tolerated. The full extent of the role of eosinophils in asthmatic patients should become clear within the next couple of years.

\section{MODULATION OF THE CHEMOATTRACTANT RECEPTOR-HOMOLOGOUS MOLECULE EXPRESSED ON $\mathrm{T}_{\mathrm{H}} \mathbf{2}$ CELLS RECEPTOR}

Prostaglandin $\mathrm{D}_{2}$ is a major lipid mediator produced (outside the brain) mainly by mast cells. It is present in increased amounts after allergen challenge, although concentrations in sputum and bronchoalveolar lavage fluid were not markedly increased in patients with clinical disease. ${ }^{48,49}$ There are 3 receptors for prostaglandin $\mathrm{D}_{2}$. The DP1 receptor is expressed on airway smooth muscle, vascular tissue, and T cells and mediates bronchodilation and immune modulation. The thromboxane receptor is expressed on airway smooth muscle and mediates bronchoconstriction. The chemoattractant receptor-homologous molecule expressed on $\mathrm{T}_{\mathrm{H}} 2$ cells (CRTH2) is a chemoattractant receptor expressed on a (small) subset of $\mathrm{T}_{\mathrm{H}} 2$ cells, eosinophils, and basophils. Antagonists of DP1 and the thromboxane receptor have not been effective in asthmatic patients. ${ }^{50}$ However, it appears relatively straightforward to make potent, orally available antagonists of CRTH2, and a number are in clinical development. ${ }^{51}$ Animal studies of asthma models involving CRTH2 have had mixed results. For example, gene deletion of CRTH2 demonstrated increased eosinophilic inflammation after short-term exposure to allergen but decreased after long-term exposure. ${ }^{52}$ A more consistent effect has been seen in murine models of atopic dermatitis with a reduction in inflammation with gene deletion. ${ }^{53}$

Despite the interest in this receptor as a target for asthma and treatment of 400 patients with anti-CRTH2 antagonists, only 1 study in asthma has been reported in the literature. Barnes et al, ${ }^{54}$ in a 1-month study of steroid-free adult subjects with moderate persistent asthma, administered $200 \mathrm{mg}$ of oral OC000549 twice daily, a potent, orally available $\mathrm{CRTH} 2$ antagonist that has previously been shown to reduce the late response after allergen challenge. Change in $\mathrm{FEV}_{1}$ was the primary outcome measure. There was a modest $(7 \%)$ improvement in $\mathrm{FEV}_{1}$, which was significant in the per-protocol population but not the full population. Quality-of-life and nighttime symptoms scores also improved. There was also a trend toward a reduction in sputum eosinophil numbers. Other selective CRTH2 antagonists have been developed for the treatment of respiratory disease but have not yet been studied in patients with asthma. ${ }^{55}$

\section{ANTAGONISTS OF ADHESION AND CHEMOKINE PATHWAYS CONTROLLING EOSINOPHIL AND $\mathrm{T}_{\mathrm{H}} \mathbf{2}$ LYMPHOCYTE MIGRATION}

Leukocyte migration into tissue is a fundamental part of the immune response, which is controlled by a combination of growth factors that produce the cells in the bone marrow, and adhesion and chemotactic pathways (in particular chemokines and their receptors) that control egress into the vasculature and migration into tissue through postcapillary venules. There are both homeostatic pathways that control immune surveillance in health, and inflammatory pathways that are switched on in an organ-specific manner when tissue injury occurs, which is where the opportunity for therapeutic intervention lies. There is a degree of specificity in the pathways controlling migration both in terms of the leukocyte and organ involved, and this encouraged the hope that it might be possible to antagonize leukocyte migration without causing intolerable immune suppression. Eosinophil adhesion to the endothelium is preferentially (compared with neutrophils) mediated by very late antigen 4 (VLA-4)-vascular cell adhesion molecule 1 and P-selectin glycoprotein ligand 1 . This is due to a relative lack of expression of VLA-4 by neutrophils and greater avidity of binding of eosinophils to P-selectin. ${ }^{56}$ However, a synthetic panselectin antagonist, bimosiamose, had relatively low potency and was a more effective antagonist of neutrophil than eosinophil adhesion. ${ }^{57,58}$ Beeh et $\mathrm{al}^{59}$ evaluated the effect of inhaled bimosiamose (TBC1269) on allergen-induced late asthmatic response in 12 adult male asthmatic patients. Bimosiamose significantly attenuated the maximum late asthmatic response by $50 \%$ compared with placebo. There was no effect on the early asthmatic response, postallergen airway hyperresponsiveness, FENO values, or peripheral blood cell numbers. 
Antibodies against P-selectin have not been tried in asthmatic patients. Vascular cell adhesion molecule 1 gene deletion is embryonically lethal in mice, and as noted below, antibodies against VLA-4 have led to major side effects (as have antibodies against lymphocyte function-associated antigen 1, a more ubiquitously functional adhesion receptor). Antagonists of chemokines or chemokine receptors have been equally slow to show promise as therapeutic agents. Chemokines are a large family of about fifty 8 - to 10-kDa cytokine chemoattractants divided into 4 families based on their structure. They bind relatively specifically to about 28 seven-transmembrane, $\mathrm{G}$ protein-linked receptors. ${ }^{60}$ Antagonists of CCR3, the major chemokine receptor involved in eosinophil migration, have great promise theoretically, and several potent antagonists have been developed. However, few clinical trials have been reported. An antisense oligonucleotide against CCR3 in combination with an antisense oligonucleotide against the common $\beta$-chain of the IL-5-GM-CSF-IL-3 family attenuated the late response to allergen challenge. ${ }^{61} \mathrm{CCR} 4$, which binds CCL17 and CCL22, has attracted a lot of attention as a relatively $\mathrm{T}_{\mathrm{H}} 2$-specific chemokine receptor that might play a role in the recruitment of $\mathrm{T}_{\mathrm{H}} 2$ cells into the lung. ${ }^{62} \mathrm{CCR} 8$ is a more specific $\mathrm{T}_{\mathrm{H}} 2$-associated receptor but is also expressed on regulatory $\mathrm{T}$ cells. ${ }^{63}$ Tian et al ${ }^{64}$ showed in a murine model of asthma that a human chemokine-like factor $1 \mathrm{C}$-terminal peptide (C19), which blocks the function of the chemokine receptor CCR4, reduced airway eosinophilia and airway hyperresponsiveness. There are no reports of the antagonists of any of these receptors in asthmatic patients.

Generally, there are not enough clinical data to determine whether antagonists of eosinophil- and $\mathrm{T}_{\mathrm{H}} 2$ lymphocyte-associated adhesion and chemokine pathways are likely to be fruitful. CXCR1 and CXCR2 are the major chemokine receptors controlling neutrophil migration, in part through binding of CXCL-8 (IL$8)$. Orally available antagonists of these receptors are in clinical trials but are not yet reported in detail, and the endotype of neutrophilic asthma is not sufficiently well understood to clearly see where these antagonists would be optimally used.

\section{IL-9 AND MORE RECENTLY DESCRIBED $\mathrm{T}_{\mathrm{H}} 2$ - ASSOCIATED CYTOKINES}

IL-9 is a pleiotropic cytokine originally described in 1990, which maps to the long arm of chromosome 5. Initially, it was thought to be a $\mathrm{T}_{\mathrm{H}}$-associated cytokine, but relatively recently, a new subset of $\mathrm{T}$ cells have been described that produce significant amounts of IL-9. However IL-9 is also produced by $\mathrm{T}_{\mathrm{H}} 17$ cells, regulatory $\mathrm{T}$ cells, eosinophils, and mast cells. ${ }^{65}$ The IL-9 receptor is a heterodimer consisting of a specific $\alpha$ chain and the common cytokine $\gamma$ chain. The receptor is expressed on mast cells, in which it promotes growth and proliferation; $\mathrm{T}$ cells; antigenpresenting cells; epithelial cells; and goblet cells. $\mathrm{T}_{\mathrm{H}} 9$ cells are produced in vitro by the combined effect of TGF- $\beta$, IL- 4 , and IL-2 and are dependent on the transcription factors PU.1 and interferon regulatory factor $4 . \mathrm{T}_{\mathrm{H}} 9$ cells produce IL-10 in mice but not in human subjects. Antagonism of IL-9, either by means of gene deletion or antibody, attenuated or abolished lung function and inflammation-related changes in an ovalbumin murine asthma model. ${ }^{66-68}$ Overexpression of IL-9 resulted in goblet cell hyperplasia, eosinophilia, and increased airways reactivity, ${ }^{69}$ possibly by inducing IL-13 expression in bronchial epithelial cells. ${ }^{70}$ There are relatively few data about IL-9 expression in asthmatic patients, although it was shown by means of in situ hybridization to be increased in bronchial biopsy specimens. ${ }^{71} \mathrm{No}$ genetic link has emerged. Clinical trials of antagonists of IL-9 appear limited to a program by MedImmune involving an $\mathrm{mAb}$ against IL-9: MEDI-528. They have reported 2 small doseranging studies in patients with mild-to-moderate asthma that demonstrated no safety concerns and suggestions of clinical benefit. ${ }^{72}$ Efficacy studies are awaited.

IL-33 is a member of the IL-1 family of cytokines that binds to ST2, a heterodimeric receptor expressed on mast cells and epithelial cells. IL-33 is produced by a wide range of cells, including alveolar macrophages and epithelial cells in the lung. As well as promoting the development of $\mathrm{T}_{\mathrm{H}} 2$ cells, IL-33 also appears pivotal in the production of the newly described IL-5- and IL-13-producing innate lymphoid cells and might therefore have a broad function in promoting eosinophilic inflammation. As yet, no clinical studies of antagonists have been reported. ${ }^{73}$

Thymic stromal lymphopoietin is an epithelium-derived cytokine that can promote $\mathrm{T}_{\mathrm{H}} 2$ patterns of inflammation by promoting the generation of $\mathrm{T}_{\mathrm{H}} 2$ cells through dendritic cell interactions and by activating mast cells. Blockade in the murine asthma model reduces inflammation, and overexpression promotes it. Expression is increased in asthmatic patients, particularly in those with more severe disease, and appears to correlate with the expression of other markers of $\mathrm{T}_{\mathrm{H}} 2$ inflammation. ${ }^{74}$ No studies of antagonists have yet been reported.

IL-25 was first described in expression libraries from $\mathrm{T}_{\mathrm{H}} 2$ cells. Overexpression in airway epithelial cells leads to eosinophilic airway inflammation, and gene deletion or neutralizing antibody resulted in reduced inflammation and airway hyperresponsiveness in the murine asthma model. ${ }^{75}$ Its effects could be mediated by promoting thymic stromal lymphopoietin/dendritic cell-activated $\mathrm{T}_{\mathrm{H}} 2$ cells or through the innate lymphoid pathway. It is expressed in the bronchial mucosa in asthmatic patients. ${ }^{76} \mathrm{No}$ antagonists have yet been reported.

In summary, as noted above, a number of approaches are being taken to inhibit the $\mathrm{T}_{\mathrm{H}} 2$ cytokine pathway. Eosinophilic inflammation, which is the hallmark of this pathway, is not found in all asthmatic patients, and thus treatment will need to be targeted by using biomarkers, such as sputum or blood eosinophils, exhaled nitric oxide, or periostin. There is increasing evidence that the physiologic hallmark of asthma, variable airflow obstruction, is only indirectly related to $\mathrm{T}_{\mathrm{H}} 2$-mediated inflammation and that the major clinical readout of this pattern of inflammation is severe exacerbations. Antagonists of the $\mathrm{T}_{\mathrm{H}} 2$ pathway might therefore be more effective against this outcome measure than classical measures of asthma improvement.

\section{INHIBITION OF T CELLS AND THEIR CORECEPTORS}

As discussed above, the $\mathrm{T}_{\mathrm{H}} 2$ pathway is important in contributing to the airway inflammation seen in asthmatic patients. In patients with severe asthma, increased numbers of activated $\mathrm{T}$ cells and increased levels of IL- 2 and soluble IL- 2 receptor $\alpha$ chain can be found in the airways. Daclizumab, a humanized $\mathrm{IgG}_{1} \mathrm{mAb}$ directed against the IL-2 receptor $\alpha$ chain (CD25) subunit of the high-affinity IL-2 receptor, inhibits IL-2 binding and its biological activity. Daclizumab is approved for use in renal allograft rejection. In a phase 2 trial Busse et $\mathrm{al}^{77}$ and, more recently, Nelson et $\mathrm{al}^{78}$ reported that daclizumab improved asthma control in a subset of patients with refractory asthma. Sornasse et $\mathrm{al}^{79}$ reported 
that daclizumab can inhibit in vitro all the major $\mathrm{T}_{\mathrm{H}} 2$ cytokines, including IL-4, IL-5, and IL-13. In a randomized placebocontrolled trial of adults with moderate-to-severe asthma, daclizumab improved $\mathrm{FEV}_{1}$, reduced daytime asthma symptoms and the use of short-acting albuterol rescue, and increased the time to first exacerbatio. ${ }^{80}$ Adverse events were similar between the treatment and placebo groups. However, 5 patients (of 88 treated with daclizumab) reported serious adverse events, including 1 patient with anaphylaxis. Daclizumab might work by blocking IL-2-induced T-cell proliferation and reducing the ability of these $\mathrm{T}$ cells to produce proinflammatory cytokines. At the present time, further development of daclizumab as asthma therapy is not planned.

$\mathrm{T}$ cells require at least 2 signals to become activated. The first signal is antigen specific and delivered through the engagement of the T-cell receptor with the MHC-peptide complex on the antigen-presenting cell (APC). The second is delivered through binding of a costimulatory receptor on $\mathrm{T}$ cells to its ligand on the APC. A key costimulatory signal is provided by the interaction of CD28 on T cells with CD80 (B7-1) or CD86 (B7-2) on APCs. ${ }^{81}$ With engagement of the T-cell receptor and the CD28 costimulatory receptor, $\mathrm{T}$ cells proliferate and produce cytokines that activate other inflammatory cells, such as macrophages and dendritic cells. Another costimulatory molecule expressed on T cells, such as cytotoxic $\mathrm{T}$ lymphocyte-associated antigen 4 , is expressed later during T-cell activation and is the high-avidity receptor for both CD80 and CD86. This interaction between cytotoxic T lymphocyte-associated antigen 4 on the T cell and its corresponding ligand on APCs provides a negative signal to the T cell to downregulate its immune reactivity. Activated T-cell interaction with APCs can be inhibited by blocking the T-cell receptor OX40. Monoclonal antibodies against OX40 ligand have been developed, and both phase 1 and proof-of-concept studies have been done in asthmatic patients.

\section{IRMS THAT AFFECT SIGNALING PATHWAYS}

The advantage of mAbs is their ability to bind to receptors expressed on the cell surface or bind and neutralize soluble mediators released from effector cells. However, mAbs cannot pass through the cell membrane and act on signaling pathways or transcription factors. However, small-molecule inhibitors can pass into the cytoplasm and can target various molecules that might interrupt the cellular machinery. Engaging certain receptors on the cell surface triggers a cascade of activation of various signaling molecules that proceeds in an orderly fashion, culminating in the activation of nuclear factor of activated $\mathrm{T}$ cells or nuclear factor $\kappa \mathrm{B}$, which then results in the differentiation of lymphocytes and the secretion of various cytokines. Inhibiting one of the molecules along such a cascade would be expected to result in inhibition of lymphocyte differentiation and cytokine secretion and might accelerate the induction of apoptosis. Several signaling pathway IRMs have been used in patients with atopic diseases.

\section{Calcineurin inhibitors}

Some of the molecules along the signaling cascade serve as a convergence point for several proximal signaling molecules. Calcineurin is one such molecule.

Cyclosporine is the prototype of calcineurin inhibitors, but tacrolimus and pimecrolimus are the ones most commonly used in patients with atopic disease because of their availability as topical agents. Both are approved by the FDA as second-line agents for the short-term treatment of moderate-to-severe atopic dermatitis in patients who are older than 2 years and immunocompetent. A subset of patients have exacerbation of their asthma on ingestion of aspirin or related products that is thought to be mediated by overproduction of cysteinyl leukotrienes. Tacrolimus, a macrolide-derived immunosuppressant, inhibits the release of cysteinyl leukotrienes. Kawano et $\mathrm{al}^{82}$ reported that tacrolimus inhibited aspirin-induced bronchoconstriction and reduced urinary leukotriene $\mathrm{E}_{4}$ excretion in patients with aspirin-induced asthma. However, Stevenson et $\mathrm{al}^{83}$ did not show a similar effect of tacrolimus to prevent aspirin-induced asthmatic reactions. In a recent study by Virtanen et al, ${ }^{84}$ longterm treatment of moderate-to-severe atopic dermatitis with topical tacrolimus decreased respiratory symptoms and bronchial hyperresponsiveness, but controlled trials are needed.

\section{Tyrosine kinase inhibitors}

Phosphorylation of various tyrosine kinases is an essential step in the activation and proliferation of lymphocytes. Tyrosine kinases are usually associated with the cytoplasmic domain of various receptors that have an extracellular domain as well. Inhibition of tyrosine kinase activity can therefore be accomplished by antibodies directed against an extracellular domain of a receptor that activates a tyrosine kinase (eg, antibodies directed against vascular endothelial growth factor, epidermal growth factor receptor, or human epidermal growth factor receptor 2). A more direct approach is the use of small molecules that inhibit (selectively or semiselectively) distinct molecules that are not expressed on the cell surface (referred to as tyrosine kinase inhibitors [TKIs]). Imatinib is the prototype of a TKI. It was initially introduced for its ability to bind Bcr-Abl, inducing apoptosis in patients with chronic myelogenous leukemia. It was later found that imatinib can also bind c-Kit and platelet-derived growth factor receptor. A subset of patients with systemic mastocytosis who have wild-type c-Kit respond favorably to imatinib. Patients with systemic mastocytosis who have the D816V kit mutation do not respond to imatinib because this mutation interferes with binding of imatinib to c-Kit. ${ }^{85} \mathrm{~A}$ subset of patients with idiopathic hypereosinophilic syndrome (those with mutations in FIP1L1/PDGFRA) have a good response to imatinib. ${ }^{86}$ Newer TKIs are available and might obviate the restrictions imposed by the mutations mentioned above on therapeutic responsiveness.

\section{Other kinase inhibitors}

Of the other kinases the modulation of which might be important in atopic diseases, spleen tyrosine kinase (Syk) has been examined most closely. Syk is expressed in most hematopoietic cells and is involved in signaling through the immunoreceptor tyrosine-based activation motif in the cytoplasmic domains of Fc $\gamma$ and Fce receptors; Syk is also involved in integrin signaling. One Syk inhibitor (R112) was found to reduce global symptom complex scores significantly as early as 45 minutes after dosing (and lasting at least up to 20 hours) in patients with allergic rhinitis. ${ }^{87}$ However, comparison of R112 with beclomethasone and placebo in a 7-day trial of allergic rhinitis found it to be 
identical to placebo. An inhaled Syk inhibitor has undergone early clinical studies in asthmatic patients.

\section{PEROXISOME PROLIFERATOR-ACTIVATED RECEPTOR AGONISTS}

Peroxisome proliferator-activated receptors (PPARs), particularly $\alpha$ and $\gamma$, can downregulate GATA-3, a key transcription factor for $\mathrm{T}_{\mathrm{H}} 2$ cytokines, and inhibit activator protein 1, signal transducer and activator of transcription 1, nuclear factor $\kappa \mathrm{B}$, and nuclear factor of activated T cells. PPAR agonists also inhibit the chemotaxis of eosinophils and antibody-dependent cellular cytotoxicity. ${ }^{88-90}$ Agonists of PPAR- $\gamma$ include the oral hypoglycemic agents thiazolidinediones, rosiglitazone, and pioglitazone. The bronchodilatory effects of rosiglitazone were demonstrated in 46 patients with mild-to-moderate asthma after 4 weeks, but no significant improvements in asthma symptoms were shown. ${ }^{91}$ Results of an open-label pilot study in 14 steroid-naive asthmatic patients given rosiglitazone demonstrated trends for improvement in airway hyperresponsiveness and $\mathrm{FEV}_{1}$ in a dose- and timedependent manner. ${ }^{92}$ The anti-inflammatory effects of thiazolidinediones (rosiglitazone) in human airway smooth muscle cells might not be mediated by PPARs. ${ }^{93}$

\section{IRMs AS ADJUVANTS FOR ALLERGEN IMMUNOTHERAPY}

Toll-like receptors (TLRs) are cell-surface or intracellular receptors that recognize pathogen-associated molecular patterns (PAMPs) commonly conserved in bacteria, viruses, and some fungi. TLRs activate both innate and adaptive immune responses and can skew the cytokine balance from $\mathrm{T}_{\mathrm{H}} 2$ toward $\mathrm{T}_{\mathrm{H}} 1$, thereby inhibiting allergic diseases. To date, 11 TLRs have been identified in human subjects. CpG oligodeoxynucleotides are short, singlestranded synthetic DNA molecules that are unmethlyated and act as immunostimulants as PAMP motifs. The CpG PAMP is recognized by TLR9, which is constitutively expressed only in B cells and plasmacytoid dendritic cells. Class A CpG oligodeoxynucleotides stimulate the production of large amounts of type I interferons, the most important being IFN- $\alpha$, and induce the maturation of plasmacytoid dendritic cells. Class A oligodeoxynucleotides are also strong activators of natural killer cells through indirect cytokine signaling. Class B oligodeoxynucleotides are strong stimulators of human B-cell and monocyte maturation. On TLR9 activation, plasmacytoid dendritic cells produce IFN- $\alpha$, IL-6, and IL-10 and induce B-cell differentiation, IgG isotype switching, and antibody production. ${ }^{94}$

Tolamba (Dynavax Technologies, Berkeley, Calif) is a B-type CpG, ISS-1018, covalently linked to the major ragweed allergen Amb a 1. A phase 2 clinical trial in 25 adults with seasonal ragweed-induced allergic rhinitis showed improvements with 6 weekly subcutaneous injections before the ragweed season of the treatment year and a subsequent ragweed season. ${ }^{95}$ However, a large, multicenter, phase 2 clinical trial did not meet its primary end point, leading to discontinuation of development. ${ }^{96}$ An inhaled form of ISS-1018 significantly increased IFN- $\gamma$ levels and IFN- $\gamma$-inducing gene expression but did not attenuate early- or late-phase asthmatic responses or reduce sputum eosinophil numbers or $\mathrm{T}_{\mathrm{H}} 2$-related gene expression. ${ }^{97}$

A-type $\mathrm{CpG}$ with and without allergen has also been studied in both patients with asthma and those with allergic rhinitis. A study of 20 patients with perennial rhinitis and house dust mite allergy demonstrated that subcutaneous allergen immunotherapy of house dust mite extract mixed with A-type ISS oligodeoxynucleotides contained in QbG10, a virus-like particle (Cytos Biotechnology, Zurich, Switzerland), over a 10-week period was well tolerated and reduced symptoms and skin test responses at least 38 weeks after treatment completion. ${ }^{98}$ In a subsequent study CYT003-QbG10 was used without allergen in 80 patients with mild-to-moderate perennial allergic rhinoconjunctivitis. Subjects received 6 weekly subcutaneous injections of CYT003-QbG10 or placebo, and after 8 weeks, the treatment group had significantly improved total rhinoconjunctivitis symptom scores, and nasal allergen provocation results improved 100 -fold. ${ }^{99,100}$

Sixty-three patients with persistent allergic asthma receiving inhaled corticosteroids received either 7 weekly subcutaneous injections of CYT003-QbG10 or placebo and were monitored over a 12-week period. During the run-in period, all subjects' symptoms were stabilized on beclomethasone, and 4 weeks later, beclomethasone was reduced by $50 \%$ and, if tolerated, reduced to zero after 4 more weeks. From weeks 6 to 12, the treatment group had significantly better combined symptom and medication scores than the placebo group and had stable $\mathrm{FEV}_{1}$ compared with that seen in the placebo group at 12 weeks. ${ }^{101}$

TLR4 (CD284), which is expressed on the cell surface and with the adaptor molecule CD14, binds LPS. Monophosphoryl lipid A (MPLA) is derived from the active component of LPS and has been used as an adjuvant in the anthrax vaccine and investigated in patients with allergic respiratory diseases. Pollinex Quattro (Allergy Therapeutics, West Sussex, United Kingdom) contains pollen extract (grass, tree, Parietaria species, or ragweed) chemically modified by glutaraldehyde and adsorbed onto an L-tyrosine depot with an MPLA adjuvant. It has been used as a preseasonal ultra-short-course immunotherapy consisting of 4 weekly subcutaneous injections. Several studies have shown clinical and immunologic benefits, which appear to be better after the second year of treatment and are sustained after a 3-year course. ${ }^{102-104}$ A recent study has demonstrated the potential of using MPLA to augment the clinical and biologic responses to sublingual immunotherapy in patients with grass allergy. ${ }^{105}$

Using a murine model of asthma, Duechs et al ${ }^{106}$ studied the effects of several different TLR agonists on airway inflammation. Both TLR7 and TLR9 agonists reduced airway eosinophilia and reduced IL-4 and IL-5 levels. In contrast, TLR2 and TLR4 agonists potentiated both eosinophilia and neutrophilia. Only the TLR7 agonist did not enhance levels of proinflammatory cytokines in lung fluids. In a similar murine model of asthma, the synthetic TLR7 ligand agonist resiquimod (R848) attenuated allergic asthma through mechanisms that required regulatory $\mathrm{T}$ cells and was mediated by TGF- $\beta .^{107,108}$ Intranasal weekly administration of a TLR8 agonist has recently been shown to improve allergic rhinitis symptoms in an allergen environmental chamber study. ${ }^{109}$

\section{ADVERSE EVENTS OF IRMs}

As with any therapeutic treatment option, there are adverse reactions associated with IRMs. ${ }^{110}$ A variety of adverse reactions have been seen with IRMs, including infections, hypersensitivity reactions, malignancies, and the cytokine release syndrome. Therapies that alter the host immune response to pathogens or 
the inflammatory response might predispose the patient to infection. Immune therapies that interfere with proinflammatory cytokines, especially the TNF inhibitors (eg, etanercept and infliximab), have a 2-fold increased risk for serious respiratory tract infections that correlates with the dosage of the IRM. Comorbid conditions, concomitant immunosuppressive medications (eg, methotrexate), and the disease entity being treated (eg, rheumatoid arthritis) might enhance the risk of infection, even without the use of an IRMs. More serious than bacterial respiratory tract infections is the increased risk of opportunistic infections in patients treated with TNF inhibitors (eg, reactivation of latent tuberculosis, Legionella species, coccidioidmycosis, histoplasmosis, and Listeria species). ${ }^{111}$ Most cases of tuberculosis were associated with reactivation of latent disease. Etanercept appears to be less of an issue with tuberculosis reactivation than infliximab. Thus in any patient treated with an IRM that affects the host response to infection, pharmacovigilance is needed.

IRMs can also be associated with an increased risk of malignancies. For example, TNF inhibitors have been associated with an increase in lymphoma and leukemia. ${ }^{112}$ However, lymphoma is increased in patients with rheumatic diseases, even without IRMs. ${ }^{113}$ Other adverse reactions by IRMs affect the neurologic system. Multiple sclerosis and other demyelinating conditions have been seen in patients treated with TNF inhibitors. ${ }^{114}$ A form of progressive multifocal encephalopathy, a brain infection caused by reactivation of latent JC virus infection, has been seen with mAbs to VLA-4 (natalizumab) and efalizumab, an $\mathrm{mAb}$ that binds to the CD11a subunit of lymphocyte functionassociated antigen 1 . Other adverse events include systemic vasculitis with anti-TNF inhibitors and cardiac arrhythmias. The development of TNF inhibitors for asthma has been halted because of limited clinical efficacy in only a subset of patients and an unacceptable side effect profile leading to an unfavorable risk/benefit ratio.

Hypersensitivity reactions are a serious adverse reaction of many of the IRMs. There are several factors that affect the development of a hypersensitivity reaction to biologic agents, especially mAbs: source of the protein (mouse vs human), route of administration, treatment programs (ie, intermittent vs continuous), and concomitant use of immunosuppressive therapies (eg, methotrexate). Hypersensitivity reactions were observed with the first FDA-approved mAb, OKT3, an mAb that was made in the mouse. ${ }^{115}$ Hypersensitivity reactions to infliximab, a chimeric mAb, commonly occur during the third or fourth infusion and can be variable, ranging from urticaria to anaphylaxis. ${ }^{116}$ In clinical trials $17 \%$ to $21 \%$ of patients and as many as $60 \%$ of patients in other studies have antibodies against infliximab. True immediate hypersensitivity reactions are in the range of $2 \%$ to $3 \%{ }^{117}$ Intermittent use of infliximab, such as in the treatment of Crohn disease, leads to greater development of antibodies. Acute infusion reactions might not be IgE mediated because reactions can occur on the first dose and most patients can tolerate subsequent infusions with premedication. ${ }^{118}$ Interestingly, the use of concomitant immunosuppressive therapies decreases the likelihood of having a reaction. Systemic reactions are less common with etanercept and adalimumab, probably because of the route of administration (ie, subcutaneous) and the nature of the IRM molecule. Patients who have hypersensitivity reactions to infliximab can be safely switched to other anti-TNF inhibitors. ${ }^{119}$ Immediate-type hypersensitivity reactions have been reported for a number of mAbs, including rituximab (5\% to $10 \%$ ), trastuzumab $(0.6 \%$ to $5 \%)$, omalizumab, natalizumab, basiliximab, abciximab, and cetuximab. All of these mAbs are either chimeric (majority) or humanized containing mouse protein. Another approach is desensitization. Brennan et al ${ }^{120}$ share their experience with hypersensitivity reactions to mAbs and desensitization protocols.

Omalizumab is a humanized $\mathrm{mAb}$ that contains approximately $5 \%$ murine protein. Although immune complexes are formed with its target IgE, there is no complement activation. The mechanisms of anaphylaxis or anaphylactoid reactions to omalizumab are currently not known. One group suggested that the excipient Polysorbate 20 might be the cause of the reactions, ${ }^{121}$ but further evaluation is needed to prove this. In clinical trials the prevalence of anaphylaxis to omalizumab was low $(0.2 \%)$, although urticaria was seen more frequently ( $4.9 \%$ in a pediatric study). ${ }^{122}$ An Omalizumab Joint Task Force reviewing the clinical trial data and the postmarketing surveillance data on reactions to omalizumab identified 35 patients and 41 episodes of anaphylaxis associated with omalizumab by using the criteria of the National Institute of Allergy and Infectious Diseases and the Food Allergy and Anaphylaxis Network ${ }^{123}$ for a rate of $0.09 \%$. Sixty-one percent of the reactions occurred in the first 2 hours after one of the first 3 doses. Five (14\%) of the reactions occurred after the fourth or later doses and within 30 minutes. These data led the group to recommend a 2-hour direct observation period with the first 3 treatments and 30 minutes thereafter for subsequent treatments. It was also recommended by this task force that all patients should be educated on the signs and symptoms of anaphylaxis and in the use and availability of the epinephrine autoinjector. ${ }^{17}$ Cruz et al ${ }^{124}$ studied the safety of omalizumab in patients with asthma at high risk for intestinal parasites. Omalizumab therapy was safe and well tolerated but was associated with a slight increase in the incidence of helminth infections.

Often confusing with these reactions to IRMs is their occurrence with the first infusion. Although some of these reactions are not immune mediated, others appear to be consistent with a hypersensitivity reaction and even an IgE-mediated process. The latter could be due to a prior sensitivity and cross-reactive antigenic determinants. Such is the case with hypersensitivity reactions to cetuximab, a chimeric mouse-human $\mathrm{IgG}_{1}$ $\mathrm{mAb}$ against the epidermal growth factor receptor, in which pre-existing IgE antibodies to the oligosaccharide galactose- $\alpha-1,3$-galactose react against the glycosylation site on the Fab portion of the heavy chain of the cetuximab molecule. ${ }^{125}$ Interestingly, the origin of these cross-reacting $\operatorname{IgE}$ antibodies to galactose- $\alpha$-1,3-galactose might be related to prior tick bites. $^{126}$

The cytokine release syndrome is a constellation of signs and symptoms ranging from flu-like symptoms to shock and is mediated by cytokine release, complement activation, and neutrophil activation, also known as the cytokine storm. Cytokine storms can occur in patients with a number of infectious and noninfectious diseases. This adverse response to IRMs was first observed with the administration of OKT3 (muromonab-CD3) in renal transplant recipients. The pathogenesis of this adverse event from $m A b s$ is related to the activation of T cells with the release of proinflammatory cytokines to produce a systemic inflammatory response. It has also been described in patients receiving rituximab with the first infusion, especially in patients treated for malignancies. The use of an anti-CD28 mAb (TGN1412) in a phase 1 trial underscores the issue of translating murine 


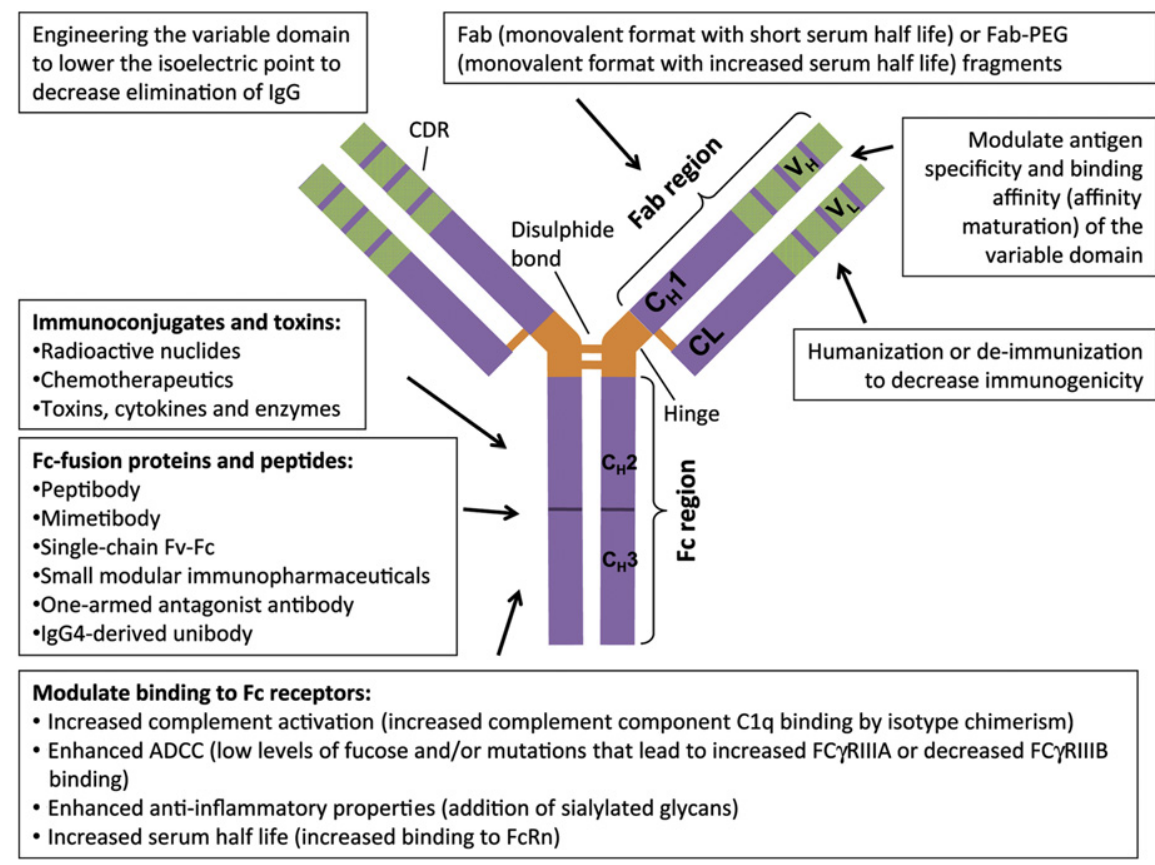

FIG 2. Strategies to improve the function of mAbs based on structure-function relationships. Adapted from Beck et al. ${ }^{128}$

experimental data to human clinical trials. This $\mathrm{mAb}$ is a superagonist that in the murine model expands $\mathrm{CD}^{+}{ }^{+} \mathrm{CD} 25^{+} \mathrm{reg}-$ ulatory $\mathrm{T}$ cells and had a potential use in the treatment of autoimmune disorders. However, when 6 healthy young male volunteers received this mAb, within 90 minutes, all had a systemic inflammatory process characterized by the release of proinflammatory cytokines and a constellation of systems consistent with a cytokine storm. ${ }^{127}$ This experience underscores the importance of being very careful in extrapolating preclinical data from an experimental model to human subjects.

\section{THE FUTURE OF IRMs}

We have come a long way since Kohler and Milstein developed their system for the production of mAbs. Monoclonal antibodies were initially all murine protein, then chimeric antibodies, then humanized antibodies in which only $5 \%$ was murine protein, and finally fully human mAbs thanks to advances in molecular biology and genetic engineering (Fig 1). A number of strategies have been developed to improve IRMs, especially mAbs. For mAbs with clinically validated targets, newer mAbs (second or third generation) are directed at the same antigen (ie, cellsurface molecule) but might target a different epitope or have improved variable domains to decrease immunogenicity, a higher affinity, or changes in the Fc domain to improve Fc function or provide a longer half-life (Fig 2). ${ }^{128}$ As we understand more about the pathogenesis and immunobiology of diseases such as asthma, new targets will be identified for treatment. Advances in structure-function relationships have led to changes in antigen binding, stability, and pharmacokinetics. Molecular and genetic engineering has led to advances in affinity maturation and enhanced target specificity. The properties of the Fc domain can be modulated by altering the glycosylation sites to regulate the anti-inflammatory properties by using site-directed mutagenesis to enhance antibody-dependent cellular cytotoxicity. Bioengineering the Fc domain can increase complement activation or increase the serum half-life by increasing the binding properties to the FcRn receptor. Another innovative approach is the engineering of bispecific antibodies that target more than 1 cell (Fig 3). For example, catumaxomab binds to both epithelial cell adhesion molecules on tumor cells and CD3 on effector T cells. ${ }^{129}$ A related approach is the dual variable domain $\operatorname{IgG}$ (DVD-IgG) technology in which the variable domains of 2 already characterized $\mathrm{mAbs}$ are joined to form a single functional, dual-specific, tetravalent IgG-like molecule. ${ }^{130}$ Advancements are also being made to decrease production and processing costs to make these IRMs more cost effective. Changes in the regulatory environment (eg, FDA policies) might lead to the faster approval and cheaper biosimilar IRMs that have come off patent. The next 10 years should be exciting and productive as advances in molecular biology and bioengineering are applied to biologic IRMs to improve their clinical efficacy by optimizing their design and developing more cost-effective production systems and purification processes. Ultimately, the production of lower-molecularweight IRMs with good risk benefits and less cost will be most useful.

Although there are many advances in the bioengineering of mAbs, other approaches are also advancing the targeting of specific molecules or RNAs.

\section{SUMMARY}

Five percent to $10 \%$ of patients with asthma have severe disease that is not responsive to mainstream controller medications. Only approximately $13 \%$ of this group meet the criteria for treatment with omalizumab, the only available FDA-approved IRM approved for asthma. Clearly, as discussed above, asthma is a complex variable heterogeneous disease. Lötvall et $\mathrm{al}^{8}$ describe 


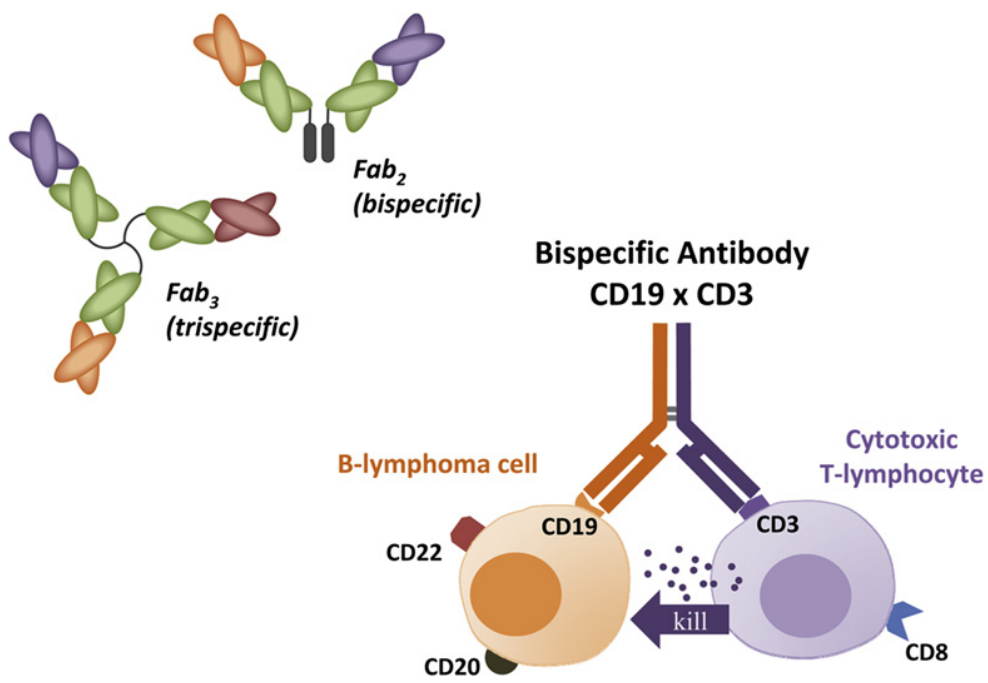

FIG 3. Examples of a bispecific antibody that binds to 2 different epitopes. These epitopes can be to the same antigen or pathogen or to 2 different targets (eg, on 2 different cells to trigger a specific function).

their approach in dividing asthma into distinct entities based not only on clinical presentations but also specific mechanisms, such as asthma endotypes.

Although the use of IRMs in the treatment of asthma and atopic disorders has not been as successful as anticipated by many or compared with their use in patients with rheumatic diseases, there have been some advances in our understanding of how to use these IRMs in disease endotypes. Although many of the studies with a variety of IRMs have shown little clinical efficacy, subset analysis of patient groups who exhibit certain characteristics, such as sputum eosinophilia, show improved primary end points and clinical efficacy that have led to new studies with a more defined patient population. A good example is the study of anti-IL-5 (mepolizumab). Recent studies of patients with eosinophilic refractory asthma ${ }^{44}$ and in patients with prednisonedependent asthma with sputum eosinophils ${ }^{41}$ have been encouraging on the use of anti-IL-5 in certain asthma endotypes. At the same time, we must continue to be vigilant for adverse events and safety while studying these IRMs, as experienced by Wenzel et $\mathrm{al}^{131}$ in a recent study of golimumab, an anti-TNF $\mathrm{mAb}$ that had an unfavorable safety profile.

Advances in the bioengineering of mAbs, fusion proteins, and small molecules that can be taken orally will be important steps in improving outcomes. For example, mAbs, perhaps bispecific antibodies, fusion proteins, or combination biologics that target more than 1 cytokine receptor or cytokine, such as pitrakinra, ${ }^{26}$ will be more successful. The biggest issue is identifying asthma endotypes to tailor the correct IRM and to evaluate carefully the best primary outcome for defined patient subpopulations. The development of useful biomarkers is critical to identify patient-specific therapies and achieve these therapeutic goals. A case in point is the study of an anti-IL-13 mAb (lebrikizumab) using blood eosinophil counts and serum periostin levels as biomarkers to identify potential asthma endotypes that would respond to this treatment approach. ${ }^{29}$

As these clinical trials point out, elucidating the pathobiology and immunology of these patient subpopulations is a critical strategy for success. The development of new biomarkers will be critical in identifying these patient endotypes for more appropriate use of specific IRMs. Novel therapies must be directed at specific asthma endotypes if these new treatment modalities are going to be clinically efficacious and brought from the bench to the bedside.

\section{REFERENCES}

1. Springer TA. Cesar Milstein, the father of modern immunology. Nat Immunol 2002;3:501-3.

2. Berry M, Morgan A, Shaw DE, Parker D, Green R, Brightling C, et al. Pathological features and inhaled corticosteroid response of eosinophilic and noneosinophilic asthma. Thorax 2007;62:1043-9.

3. Wardlaw AJ, Silverman M, Siva R, Pavord ID, Green R. Multi-dimensional phenotyping: towards a new taxonomy for airway disease. Clin Exp Allergy 2005;35:1254-62.

4. Wenzel SE. Asthma: defining of the persistent adult phenotypes. Lancet 2006; 368:804-13.

5. Halder P, Pavord ID, Shaw DE, Berry MA, Thomas M, Brightling CE, et al. Cluster analysis and clinical asthma phenotypes. Am J Respir Crit Care Med 2008;178: 218-24.

6. Simpson JL, Scott R, Boyle MJ, Gibson PG. Inflammatory subtypes in asthma: assessment and identification using induced sputum. Respirology 2006;11:54-61.

7. Anderson GP. Endotyping asthma: new insights into key pathogenic mechanisms in a complex, heterogenous disease. Lancet 2008;372:1107-19.

8. Lötvall J, Akdis CA, Bacharier LB, Bjermer L, Casale TB, Custovic A, et al. Asthma endotypes: a new approach to classification of disease entities within the asthma syndrome. J Allergy Clin Immunol 2011;127:355-60.

9. Lin H, Boesel KM, Griffith DT, Prussin C, Foster B, Romero FA, et al. Omalizumab rapidly decreases nasal allergic response and FcepsilonRI on basophils. J Allergy Clin Immunol 2004;113:297-302.

10. Prussin C, Griffith DT, Boesel KM, Lin H, Foster B, Casale TB. Omalizumab treatment downregulates dendritic cell FcepsilonRI expression. J Allergy Clin Immunol 2003;112:1147-54.

11. Djukanovic R, Wilson SJ, Kraft M, Jarjour NN, Steel M, Chung KF, et al. Effects of treatment with anti-immunoglobulin $\mathrm{E}$ antibody omalizumab on airway inflammation in allergic asthma. Am J Respir Crit Care Med 2004;170:583-93.

12. Rodrigo GJ, Neffen H, Castro-Rodriguez JA. Efficacy and safety of subcutaneous omalizumab versus placebo as add on therapy to corticosteroids for children and adults with asthma: a systematic review. Chest 2011;139:28-35.

13. Slavin RG, Ferioli D, Tannenbaum S, Martin C, Blogg M, Lowe PJ. Asthma symptom re-emergence after omalizumab withdrawal correlates well with increasing IgE and decreasing pharmacokinetic concentrations. J Allergy Clin Immunol 2009;123:107-13, e3.

14. MacGlashan D Jr. Therapeutic efficacy of omalizumab. J Allergy Clin Immunol 2009; $123: 114-5$.

15. Bousquet J, Siergiejko Z, Swiebocka E, Humbert M, Rabe K, Smith N, et al. Persistency of response to omalizumab therapy in severe allergic (IgE-mediated) asthma. Allergy 2011;66:671-8. 
16. Nopp A, Johansson SGO, Adédoyin J, Ankerst J, Palmqvist M, Öman H. After 6 years with Xolair; a 3-year withdrawal follow-up. Allergy 2010;65:56-60.

17. Cox L, Platts-Mills TAE, Finegold I, Schwartz L, Simons ER, Wallace DV. American Academy of Allergy, Asthma \& Immunology/American College of Allergy, Asthma and Immunology Joint Task Force Report on omalizumab-associated anaphylaxis. J Allergy Clin Immunol 2007;120:1373-7.

18. Tan R, Corren J. Omalizumab in the treatment of asthma. Expert Rev Respir Med 2011;5:747-56.

19. Casale T, Busse W, Kline J, Ballas Z, Moss M, Townley R, et al. Omalizumab pretreatment decreases acute reactions after rush immunotherapy for ragweedinduced seasonal allergic rhinitis. J Allergy Clin Immunol 2006;117:134-40.

20. Parks K, Casale T. Anti-immunoglobulin E monoclonal antibody administered with immunotherapy. Allergy Asthma Proc 2006;27(suppl):S33-6.

21. Lane J, Cheyney J, Lane T, Kent D, Cohen D. Treatment of recalcitrant atopic dermatitis with omalizumab. J Am Acad Dermatol 2006;54:68-72.

22. Warrier P, Casale T. Omalizumab in idiopathic anaphylaxis. Ann Allergy Asthma Immunol 2009;102:257-8.

23. Woodruff PG, Modrek B, Choy DF, Jia G, Abbas AR, Ellwanger A, et al. T-helper type 2-driven inflammation defines major subphenotypes of asthma. Am J Respir Crit Care Med 2009;180:388-95.

24. Borish LC, Nelson HS, Lanz MJ, Claussen L, Whitmore JB, Agosti IM, et al. Interleukin-4 receptor in moderate atopic asthma. A phase I/II randomized, placebo-controlled trial. Am J Respir Crit Care Med 1999;160:1816-23.

25. Borish LC, Nelson HS, Corren J, Bensch G, Busse WW, Whitmore JB, et al. Efficacy of soluble IL-4 receptor for the treatment of adults with asthma. J Allergy Clin Immunol 2001;107:963-70.

26. Wenzel S, Wilbraham D, Fuller R, Getz EB, Longphre M. Effect of an interleukin-4 variant on late phase asthmatic response to allergen challenge in asthmatic patients: results of two phase 2a studies. Lancet 2007;370:1422-31.

27. Corren J, Busse W, Meltzer EO, Mansfield L, Bensch G, Fahrenholz J, et al. A randomized, controlled, phase 2 study of AMG317, an IL-4R $\alpha$ antagonist, in patients with asthma. Am J Respir Crit Care Med 2010;181:788-96.

28. Gauvreau GM, Boulet LP, Cockcroft DW, Fitzgerald JM, Carlsten C, Davis BE, et al. Effects of interleukin-13 blockade on allergen-induced airway responses in mild atopic asthma. Am J Respir Crit Care Med 2011;183:1007-14.

29. Corren J, Lemanske RF, Hanania NA, Korenblat PE, Merdad MV, Arron JR, et al Lebrikizumab treatment in adults with asthma. N Engl J Med 2011;365:1088-98.

30. Wardlaw AJ, Kay AB. The role of the eosinophil in the pathogenesis of asthma. Allergy 1987;42:321-35

31. Wardlaw AJ, Dunnette S, Gleich GJ, Collins JV, Kay AB. Eosinophils and mast cells in bronchoalveolar lavage in subjects with mild asthma. Relationship to bronchial hyperreactivity. Am Rev Respir Dis 1988;137:62-9.

32. Leckie MJ, ten Brinke A, Khan J, Diamant Z, O'Connor BJ, Walls CM, et al. Effects of an interleukin-5 blocking monoclonal antibody on eosinophils, airway hyper-responsiveness, and the late asthmatic response. Lancet 2000;356:2144-8.

33. Flood-Page P, Swenson C, Faiferman I, Matthews J, Williams M, Brannick L, et al. A study to evaluate safety and efficacy of mepolizumab in patients with moderate persistent asthma. Am J Respir Crit Care Med 2007;176:1062-71.

34. Kips JC, O'Connor BJ, Langley SJ, Woodcock A, Kerstjens HAM, Postma DS, et al. Effect of SCH55700, a humanized anti-human interleukin-5 antibody, in severe persistent asthma. Am J Respir Crit Care Med 2003;167:1655-9.

35. Haldar P, Pavord ID, Shaw DE, Berry MA, Thomas M, Brightling CE, et al. Cluster analysis and clinical asthma phenotypes. Am J Respir Crit Care Med 2008; 178:218-24

36. Pavord ID, Brightling CE, Woltmann G, Wardlaw AJ. Non-eosinophilic corticosteroid unresponsive asthma [letter]. Lancet 1999;353:2213-4.

37. Flood-Page P, Menzies-Gow A, Kay AB, Robinson DS. Eosinophil's role remains uncertain as anti-interleukin-5 only partially depletes numbers in asthmatic airway. Am J Respir Crit Care Med 2003;167:199-204

38. Wardlaw AJ, Brightling CE, Green R, Woltmann G, Bradding P, Pavord ID. New insights into the relationship between airway inflammation and asthma. Clin Sci (Lond) 2002;103:201-11.

39. Pavord ID, Wardlaw AJ. The A to E of airway disease. Clin Exp Allergy 2010;40:62-7.

40. Green RH, Brightling CE, McKenna S, Hargadon B, Parker D, Bradding P, et al. Asthma exacerbations and sputum eosinophil counts: a randomised controlled trial. Lancet 2002;360:1715-21.

41. Nair P, Pizzichini MMM, Kjarsgaard M, Inman MD, Efthimiadis A, Pizzichini E, et al. Mepolizumab for prednisone-dependent asthma with sputum eosinophilia. N Eng J Med 2009;360:985-93.

42. Wenzel SE. Eosinophils in asthma-closing the loop or opening the door? N Engl J Med 2009;360:1026-8.

43. Rothenberg ME, Klion AD, Roufosse FE, Kahn JE, Weller PF, Simon HU, et al Treatment of patients with hypereosinophilic syndrome with mepolizumab. N Engl J Med 2008;358:1215-28.
44. Halder P, Brightling CE, Hargadon B, Cupta S, Monteiro W, Sousa A, et al. Mepolizumab and exacerbations of refractory eosinophilic asthma. N Engl J Med 2009;360:973-84.

45. Flood-Page P, Menzies-Gow A, Phipps S, Ying S, Wangoo A, Ludwig MS, et al. Anti-IL-5 treatment reduces deposition of ECM proteins in the bronchial subepithelial basement membrane of mild atopic asthmatics. J Clin Invest 2003;112: 1029-36

46. Castro M, Mathur S, Hargreave F, Boulet LP, Xie F, Young J, et al. Reslizumab for poorly controlled, eosinophilic asthma: a randomized, placebo-controlled study. Am J Respir Crit Care Med 2011;184:1125-32.

47. Kolbeck R, Kozhich A, Koike M, Peng L, Andersson CK, Damschroder MM, et al. MEDI-563, a humanized anti-IL-5 receptor alpha mAb with enhanced antibody-dependent cell-mediated cytotoxicity function. J Allergy Clin Immunol 2010;125:1344-53, e2.

48. Brightling CE, Ward R, Woltmann G, Bradding P, Sheller JR, Dworski R, et al. Induced sputum inflammatory mediator concentrations in eosinophilic bronchitis and asthma. Am J Respir Crit Care Med 2000;162:878-82.

49. Mutalithas K, Guillen C, Day C, Brightling CE, Pavord ID, Wardlaw AJ. CRTH2 expression on T cells in asthma. Clin Exp Immunol 2010;161:34-40.

50. Pettipher R, Hansel TT, Armer R. Antagonism of the prostaglandin D2 receptors DPI and CRTH2 as an approach to treat allergic diseases. Nat Rev Drug Discov 2007;6:313-25

51. Ulven T, Kostenis E. Novel CRTH2 antagonists: a review of patents from 2006 to 2009. Expert Opin Ther Pat 2010;20:1505-30.

52. Chevalier E, Stock J, Fisher T, Dupont M, Fric M, Fargeau H, et al. Cutting edge: chemoattractant receptor-homologous molecule expressed on Th2 cells plays a restricting role on IL-5 production and eosinophil recruitment. J Immunol 2005; $175: 2056-60$

53. Satoh T, Moroi R, Aritake K, Urade Y, Kanai Y, Sumi K, et al. Prostaglandin D2 plays an essential role in chronic allergic inflammation of the skin via CRTH2 receptor. J Immunol 2006;177:2621-9.

54. Barnes NB, Pavord ID, Chuchalin A, Bell J, Hunter M, Lewis T, et al. A randomized, double-blind, placebo-controlled study of the CRTH2 antagonist OC00459 in moderate persistent asthma. Clin Exp Allergy 2012;42:38-48.

55. Gallant M, Beaulieu C, Berthelette C, Colucci J, Crackower M, Dalton C, et al. Discovery of MK-7246, a selective CRTH2 antagonist for the treatment of respiratory diseases. Bioorg Med Chem Lett 2011;21:288-93.

56. Wardlaw AJ. Molecular basis for selective eosinophil trafficking in asthma: a multistep paradigm. J Allergy Clin Immunol 1999;104:917-26.

57. Davenpeck KL, Berens KL, Dixon RA, Dupre B, Bochner BS. Inhibition of adhesion of human neutrophils and eosinophils to P-selectin by the sialyl Lewis antagonist TBC1269: preferential activity against neutrophil adhesion in vitro. J Allergy Clin Immunol 2000;105:769-75.

58. Woodside DG, Vanderslice P. Cell adhesion antagonists: therapeutic potential in asthma and chronic obstructive pulmonary disease. BioDrugs 2008;22:85-100.

59. Beeh K, Beier J, Meyer M, Buhl R, Zahlten R, Wolff G. Bimosiamose, an inhaled small molecule pan-selectin antagonist, attenuates late asthmatic reactions following allergen challenge in mild asthmatics: a randomized, double-blind, placebo-controlled clinical cross-over trial. Pulm Pharmacol Ther 2006;19: 233-41.

60. Pease JE. Targeting chemokine receptors in allergic disease. Biochem J 2011;434: 11-24.

61. Gauvrear GM, Boulet LP, Cockcroft DW, Baatjes A, Cote J, Deschesnes F, et al. Antisense therapy against CCR3 and the common beta chain attenuates allergeninduced eosinophilic responses. Am J Respir Crit Care Med 2008;177:952-8.

62. Vijayanand P, Durkin K, Hartmann G, Morjaria J, Seumois G, Staples KJ, et al. Chemokine receptor 4 plays a key role in $\mathrm{T}$ cell recruitment into the airways of asthmatic patients. J Immunol 2010;184:4568-74.

63. Mutalithas K, Guillen C, Raport C, Kolbeck R, Soler D, Brightling CE, et al. Expression of CCR8 is increased in asthma. Clin Exp Allergy 2010;40:1175-85.

64. Tian L, Li W, Wang J, Zhang Y, Zheng Y, Qi H, et al. The CKLF1C19 peptide attenuates allergic lung inflammation by inhibiting CCR3 and CCR4-mediated chemotaxis in a mouse model of asthma. Allergy 2011;66: 287-97.

65. Goswami R, Kaplan MH. A brief history of IL-9. J Immunol 2011;186:3283-8.

66. Chang HC, Sehra S, Goswami R, Yao W, Yu Q, Stritesky GL, et al. The transcription factor PU.1 is required for the development of IL-9-producing T cells and allergic inflammation. Nat Immunol 2010;11:527-34.

67. Kearley J, Erjefalt JS, Andersson CK, Benjamin E, Jones CP, Robichaud A, et al. IL-9 governs allergen-induced mast cell numbers in the lung and chronic remodeling of the airways. Am J Respir Crit Care Med 2011;183:865-75.

68. Staudt V, Bothur E, Klein M, Lingnau K, Reuter S, Grebe N, et al. Interferon-regulatory factor 4 is essential for the developmental program of $\mathrm{T}$ helper 9 cells. Immunity 2010;33:192-202. 
69. Temann UA, Geba GP, Rankin JA, Flavell RA. Expression of interleukin 9 in the lungs of transgenic mice causes airway inflammation, mast cell hyperplasia, and bronchial hyperresponsiveness. J Exp Med 1998;188:1307-20.

70. Temann UA, Laouar Y, Eynon EE, Homer R, Flavell RA. IL9 leads to airway inflammation by inducing IL13 expression in airway epithelial cells. Int Immunol 2007;19:1-10.

71. Shimbara A, Christodoulopoulos P, Soussi-Gounni A, Olivenstein R, Nakamura $\mathrm{Y}$, Levitt RC, et al. IL-9 and its receptor in allergic and nonallergic lung disease: increased expression in asthma. J Allergy Clin Immunol 2000;105:108-15.

72. Parker JM, Oh CK, LaForce C, Miller SD, Pearlman DS, Le C, et al. Safety profile and clinical activity of multiple subcutaneous doses of MEDI-528, a humanized anti-interleukin-9 monoclonal antibody, in two randomized phase 2a studies in subjects with asthma. BMC Pulm Med 2011;11:11-21.

73. Smith DE. IL-33: a tissue derived cytokine pathway involved in allergic inflammation and asthma. Clin Exp Allergy 2010;40:200-8.

74. Shikotra A, Choy DF, Ohri CM, Doran E, Butler C, Hargadon B, et al. Increased expression of immunoreactive thymic stromal lymphopoietin in patients with severe asthma. J Allergy Clin Immunol 2012;129:104-11, e1-9.

75. Oliphant CJ, Barlow JL, McKenzie AN. Insights into the initiation of type 2 immune responses. Immunology 2011;134:378-85.

76. Corrigan CJ, Wang W, Meng Q, Fang C, Eid G, Caballero MR, et al. Allergeninduced expression of IL-25 and IL-25 receptor in atopic asthmatic airways and late-phase cutaneous responses. J Allergy Clin Immunol 2011;128:116-24.

77. Busse WW, Baker JW, Charous BL, Chervinsky P, Kim KT, Gross GN, et al. Preliminary safety and efficacy of daclizumab in the treatment of patients with moderate to severe chronic persistent asthma. J Allergy Clin Immunol 2004; 113(suppl):S286.

78. Nelson HS, Busse WW, Israel E, Baker JW, Charous BL, Kim KT, et al. Daclizumab improves asthma control in patients with refractory asthma. J Allergy Clin Immunol 2005;115(suppl):S134.

79. Sornasse TR, Hong W, Schreck R, Zhang Y, Sheridan J, Shi J, et al. Daclizumab in vitro inhibits the secretion of pro-asthmatic and pro-inflammatory cytokines by activated T-cells. J Allergy Clin Immunol 2005;115(suppl):S73.

80. Busse WW, Israel E, Nelson HS, Baker JW, Charous BL, Young DY, et al. Daclizumab improves asthma control in patients with moderate to severe persistent asthma. Am J Respir Crit Care Med 2008;178:1002-8.

81. Reiser H, Stadecker MJ. Costimulatory B7 molecules in the pathogenesis of infectious and autoimmune diseases. N Engl J med 1996;335:1369-77.

82. Kawano T, Matsuse H, Kondo Y, Machida I, Saeki S, Tomari S, et al. Tacrolimus reduces urinary excretion of leukotriene $\mathrm{E}(4)$ and inhibits aspirin-induced asthma to threshold dose of aspirin. J Allergy Clin Immunol 2004;114:1278-81.

83. Stevenson DD, Mehra PK, White AA, Gupta S, Woessner KM, Simon RA. Failure of tacrolimus to prevent aspirin-induced respiratory reactions in patients with aspirin-exacerbated respiratory disease. J Allergy Clin Immunol 2005;116:755-60.

84. Virtanen H, Remitz A, Malmberg P, Rytilä P, Metso T, Haahtela T, et al. Topical tacrolimus in the treatment of atopic dermatitis-does it benefit the airways? A 4-year open follow-up. J Allergy Clin Immunol 2007;120:1464-6.

85. Mol CD, Dougan DR, Schneider TR, Skene RJ, Kraus ML, Scheibe DN, et al. Structural basis for the autoinhibition and STI-571 inhibition of c-Kit tyrosine kinase. J Biol Chem 2004;279:31655-63.

86. Ogbogu PU, Bochner BS, Butterfield JH, Gleich GJ, Huss-Marp J, Kahn JE, et al Hypereosinophilic syndrome: a multicenter, retrospective analysis of clinical characteristics and response to therapy. J Allergy Clin Immunol 2009;124: 1319-1325e

87. Meltzer EO, Hamilos DL, Hadley JA, Lanza DC, Marple BF, Nicklas RA, et al. Rhinosinusitis: Developing guidance for clinical trials. J Allergy Clin Immunol 2006;118(suppl):S17-61

88. Belvisi MG, Hele DJ. Peroxisome proliferator-activated receptors as novel targets in lung disease. Chest 2008;134:152-7.

89. Denning GM, Stoll LL. Peroxisome proliferator-activated receptors: potential therapeutic targets in lung disease? Pediatr Pulmonol 2006;41:23-34.

90. Woerly G, Honda K, Loyens M, Papin JP, Auwerx M, Staels B, et al. Peroxisome proliferator-activated receptors alpha and gamma down-regulate allergic inflammation and eosinophil activation. J Exp Med 2003;198:411-21.

91. Spears M, Donnelly I, Jolly L, Brannigan M, Ito K, McSharry C, et al. Bronchodilatory effect of the PPAR-gamma agonist rosiglitazone in smokers with asthma. Clin Pharmacol Ther 2009;86:49-53.

92. Sandhu MS, Dimov V, Romero T, Wichman T, Casale TB. Effects of rosiglitazone on airway hyperresponsiveness and obstruction in asthma. J Allergy Clin Immunol 2010;5:AB66.

93. Zhu M, Flynt L, Ghosh S, Mellema M, Banerjee A, Williams E, et al. Anti-inflammatory effects of thiazolidinediones in human airway smooth muscle cells. Am J Respir Cell Mol Biol 2011;45:111-9.
94. Krieg AM. Therapeutic potential of toll-like receptor 9 activation. Nat Rev Drug Discov 2006;5:471-84.

95. Creticos PS, Schroeder JT, Hamilton RG, Balcer-Whaley SL, Khattignavong AP, Lindblad R, et al. Immunotherapy with a ragweed-toll-like receptor 9 agonist vaccine for allergic rhinitis. N Engl J Med 2006;355:1445-55

96. Bernstein D, Segall N, Nayak A, Casale T, Korenblat P, Martins E. Safety and efficacy of the novel vaccine Tolamba in ragweed allergic adults, a dose finding study. J Allergy Clin Immunol 2007;119(suppl):S78-9.

97. Gauvreau GM, Hessel EM, Boulet L, Coffman RL, O’Byrne PM. Immunostimulatory sequences regulate interferon-inducible genes but not allergic airway responses. Am J Respir Crit Care Med 2006;174:15-20.

98. Senti G, Johansen P, Haug S, Bull C, Gottschaller C, Muller P, et al. Use of A-type $\mathrm{CpG}$ oligodeoxynucleotides as an adjuvant in allergen-specific immunotherapy in humans: a phase I/IIa clinical trial. Clin Exp Allergy 2009, 39:562-70.

99. Klimek L, Willers J, Hammann-Haenni A, Pfaar O, Stocker H, Mueller P, et al Assessment of clinical efficacy of CYT003-QbG10 in patients with allergic rhinoconjunctivitis: a phase IIb study. Clin Exp Allergy 2011;41:1305-12.

100. Blaziene A, Leisyte P, Sitkauskine B, Kits L, Savisaar M, Lozovskis V, et al. CYT003-QbG10, a novel allergen-independent immunotherapy, shown to be safe and efficacious in placebo-controlled phase II study. Ann Allergy Asthma Immunol 2009;102:A8.

101. Renner W, Beeh K, Schilder C, Wagner F, Kanniess F, Naudts I, et al. Novel TLR9 agonist CYT003-QbG10 shown to improve asthma control in placebocontrolled phase II clinical trial. Am J Respir Crit Care Med 2011;183:A4063.

102. Musarra A, Bignardi D, Troise C, Passalacqua G. Long-lasting effect of a monophosphoryl lipid-adjuvanted immunotherapy to Parietaria. A controlled field study. Eur Ann Allergy Clin Immunol 2010;42:115-9.

103. Rosewich M. Ultra-short course immunotherapy in children and adolescents during a 3-yrs post-marketing surveillance study. Pediatr Allergy Immunol 2009;21:e185-9.

104. Rosewich M, Schulze J, Eickmeier O, Telles T, Rose MA, Schubert R, et al. Tolerance induction after specific immunotherapy with pollen allergoids adjuvanted by monophosphoryl lipid A in children. Clin Exp Immunol 2010;160:403-10.

105. Pfaar O, Barth C, Jaschke C, Hormann K, Klimek L. Sublingual allergen-specific immunotherapy adjuvanted with monophosphoryl lipid A: a phase I/IIa study. Int Arch Allergy Immunol 2010;154:336-44.

106. Duechs MJ, Hahn C, Benediktus E, Werner-Klein M, Braun A, Hoymann HG, et al. TLR agonist mediated suppression of allergic responses is associated with increased innate inflammation in the airways. Pulm Pharmacol Ther 2011;24:203-14.

107. Van LP, Bardel E, Gregoire S, Vanoirbeek J, Schneider E, Dy M, et al. Treatment with the TLR7 agonist R848 induces regulatory T-cell-mediated suppression of established asthma symptoms. Eur J Immunol 2011;41:1992-9.

108. Xirakia C, Koltsida O, Stavropoulos A, Thanassopoulou A, Aidinis V, Sideras P, et al. Toll-like receptor 7-triggered immune response in the lung mediates acute and long-lasting suppression of experimental asthma. Am J Respir Crit Care Med 2010;181:1207-16

109. Horak F, Zieglmayer P, Zieglmayer R, Lemell P, Newkirk M, Manjarrez K, et al. Intranasal TLR 8 agonist (VTX-1463) significantly improves symptoms of allergic rhinitis in a randomized, placebo-controlled trial. J Allergy Clin Immunol 2011;127:AB199.

110. Lee SJ, Kavanaugh A. Adverse reactions to biologic agents: focus on autoimmune disease therapies. J Allergy Clin Immunol 2005;116:900-5.

111. Bieber J, Kavanaugh A. Consideration of the risk and treatment of TB in patients with rheumatoid arthritis receiving biologic treatments. Rheum Dis Clin North Am 2004;30:257-70.

112. van Vollenhoven RF. Benefits and risks of biological agents: lymphomas. Clin Exp Allergy 2004;22(suppl):S122-5.

113. Koivuniemi R, Paimela L, Suomalainen R, Leirisalo-Repo M. Malignancies in patients with rheumatoid arthritis. Scand J Rheumatol 2011;40:154-5.

114. Magnano M, Robinson WH, Genovese MC. Demyelination and the use of TNF inhibition. Clin Exp Allergy 2004;22(suppl):S134-40.

115. Abramowicz D, Crusiaux A, Goldman M. Anaphylactic shock after retreatmen with OKT3 monoclonal antibody. N Engl J Med 1992;327:736.

116. Wasserman MJ, Weber DA, Guthrie JA, Bykerk VP, Lee P, Keystone EC. Infusion-related reactions to infliximab in patients with rheumatoid arthritis in a clinical practice setting: relationship to dose, anti-histamine pre-treatment, and infusion number. J Rheumatol 2004;31:1912-7.

117. Baert F, Norman M, Vermeire S, Van Assche G, D'Haens G, Carbonez A, et al. Influence of immunogenicity on the long-term efficacy of infliximab in Crohn's disease. N Engl J Med 2003;348:601-8.

118. Campi P, Benucci M, Manfredi M, Demoly P. Hypersensitivity reactions to biological agents with special emphasis on tumor necrosis factor- $\alpha$ antagonists. Curr Opin Allergy Clin Immunol 2007;7:393-403 
119. Youdim A, Vasiliauskas EA, Targan SR, Papadakis KA, Ippoliti A, Dubinsky MC et al. A pilot study of adalimumab in infliximab-allergic patients. Inflamm Bowel Dis 2004;10:333-8.

120. Brennan P, Bouza TR, Hsu FI, Sloane DE. Hypersensitivity reactions to monoclonal antibodies: 105 desensitizations in 23 patients, from evaluation to treatment. J Allergy Clin Immunol 2009;124:1259-66.

121. Price KS, Hamilton RG. Anaphylactoid reactions in two patients after omalizumab administration after successful long-term therapy. Allergy Asthma Proc 2007;28:313-9.

122. Berger W, Gupta N, McAlary M, Fowler-Taylor A. Evaluation of long-term safety of the anti-IgE antibody, omalizumab, in children with allergic asthma. Ann Allergy Asthma Immunol 2003;91:182-8.

123. Sampson HA, Munoz-Furlong A, Campbell RL, Adkinson NF Jr, Bock SA, Branum A. Second symposium on the definition and management of anaphylaxis: summary report-Second National Institute of Allergy and Infectious Disease/ Food Allergy and Anaphylaxis Network symposium. J Allergy Clin Immunol 2006;117:391-7.

124. Cruz AA, Lima F, Sarinho E, Ayre G, Martin C, Fox H, et al. Safety of antiimmunoglobulin $\mathrm{E}$ therapy with omalizumab in allergic patients at risk of geohelminth infection. Clin Exp Allergy 2007;37:197-207.
125. Chung CH, Mirakhur B, Chan E, Le QT, Berlin J, Morse M, et al. Cetuximab-induced anaphylaxis and IgE specific for galactose $\alpha$-1,3-galactose. N Eng J Med 2008;358:1109-17.

126. Commins SP, Platts-Mills TAE. Allergenicity of carbohydrates and their role in anaphylactic events. Curr Allergy Asthma Rep 2010;10: 29-33.

127. Suntharalingam G, Perry MR, Ward S, Brett SJ, Castello-Cortes A, Brunner MD, et al. Cytokine storm in a phase 1 trial of the anti-CD28 monoclonal antibody TGN1412. N Engl J Med 2006;355:1018-28.

128. Beck A, Wurch T, Bailly C, Corvaia N. Strategies and challenges for the next generation of therapeutic antibodies. Nat Rev Immunol 2010;10:345-52.

129. Linke R, Klein A, Steimetz D. Catumaxomab: clinical development and future directions. MAbs 2010;2:129-36.

130. Wu C, Ying H, Bose S, Miller R, Medina L, Santora L, et al. Molecular construction and optimization of anti-human IL- $1 \alpha / \beta$ dual variable domain immunoglobulin (DVD-Ig) molecules. MAbs 2009;1:339-47.

131. Wenzel SE, Barnes PJ, Bleecker ER, Bousquet J, Busse W, Dahlén SE, et al. A randomized, double-blind, placebo-controlled study of tumor necrosis factoralpha blockade in severe persistent asthma. Am J Respir Crit Care Med 2009; 179:549-58. 